\title{
Human capital factors at the firm level
}

Citation for published version (APA):

Cörvers, F. (1994). Human capital factors at the firm level. Researchcentrum voor Onderwijs en Arbeidsmarkt, Faculteit der Economische Wetenschappen. ROA Working Papers No. 7E https://doi.org/10.26481/umarow.199407E

Document status and date:

Published: 01/01/1994

DOI:

10.26481/umarow.199407E

Document Version:

Publisher's PDF, also known as Version of record

\section{Please check the document version of this publication:}

- A submitted manuscript is the version of the article upon submission and before peer-review. There can be important differences between the submitted version and the official published version of record.

People interested in the research are advised to contact the author for the final version of the publication, or visit the DOI to the publisher's website.

- The final author version and the galley proof are versions of the publication after peer review.

- The final published version features the final layout of the paper including the volume, issue and page numbers.

Link to publication

\footnotetext{
General rights rights.

- You may freely distribute the URL identifying the publication in the public portal. please follow below link for the End User Agreement:

www.umlib.nl/taverne-license

Take down policy

If you believe that this document breaches copyright please contact us at:

repository@maastrichtuniversity.nl

providing details and we will investigate your claim.
}

Copyright and moral rights for the publications made accessible in the public portal are retained by the authors and/or other copyright owners and it is a condition of accessing publications that users recognise and abide by the legal requirements associated with these

- Users may download and print one copy of any publication from the public portal for the purpose of private study or research.

- You may not further distribute the material or use it for any profit-making activity or commercial gain

If the publication is distributed under the terms of Article $25 \mathrm{fa}$ of the Dutch Copyright Act, indicated by the "Taverne" license above, 


\section{Human Capital Factors at the Firm Level}

Frank Cörvers

ROA-W-1994/7E

Research Centre for Education and the Labour Market

Faculty of Economics and Business Administration

University of Limburg

Maastricht, November 1994 


\section{CIP-GEGEVENS KONINKLIJKE BIBLIOTHEEK, DEN HAAG}

\section{Cörvers, Frank}

Human Capital factors at the firm level / Frank Cörvers. - Maastricht : Research Centre for Education and the Labour Market, Faculty of Economics and Business Administration, University of Limburg. ([Working paper]/Research Centre for Education and the Labour Market, ISSN 0922-4645 ; ROA-W1994/7E)

With ref.

ISBN 90-5321-142-X

Subject headings: human capital / labour economy. 


\section{Contents}

Abstract

1 Introduction

2 Initial Schooling

2.1 Education and labour productivity

3

2.2 Effective labour input

2.3 A partial labour market model

3 Training, learning and skill obsolescence

3.1 Investment in training

3.2 Learning-by-doing

3.3 Substitution between different forms of human capital

3.4 Skills obsolescence

4 Techn(olog)ical change and the demand for human capital

4.1 Technical and technological change

4.2 Technological knowledge, R\&D and diffusion

4.3 Technology-skill complementarities

5 Conclusions

References

Appendix A

Appendix B 



\begin{abstract}
This paper aims to give a survey of the literature on the various forms of human capital which are relevant at the firm level, as a first step towards the development of human capital indicators for the international competitiveness of economic sectors. Therefore the relationship between, on the one hand, human capital and, on the other hand, productivity and wages will be particularly emphasized throughout the paper. The paper considers initial schooling, training and learning-by-doing, all from the perspective of the firm. The substitutability and complementarity between these human capital forms and the obsolescence of human capital will also be briefly discussed. Finally, the relationship between technical and technological change and human capital will be dealt with.
\end{abstract}





\section{Introduction ${ }^{1}$}

This paper is written as part of the PhD project "Human Capital and the International Competitiveness of Sectors". One of the purposes of the project is to develop human capital indicators that can measure competitiveness. This paper is a first step towards the development of such indicators. It attempts to give an overview of the various forms of human capital that can be distinguished at the firm level. Moreover, since investments in technology are often regarded as a way to strengthen competitiveness, the paper will also focus on the relationship between technological change and human capital.

Standard economic theory traditionally considers homogeneous capital and homogeneous labour as the only two production factors in a production function. However, nowadays it is commonly accepted that human capital is a relevant production factor too. This is illustrated by studies explaining national economic growth. These studies regard education or human capital as an important factor input (for example Rasmussen and Kim, 1992, and McMahon, 1984). Microeconometric studies on the estimation of the production function of the firm also show the relevance of human capital as a production factor, since they often allow for different educational categories of labour input (for example Broer and Jansen, 1989, and Hebbink, 1992).

Schultz (1961) distinguishes five forms of human capital investment, namely health facilities and services, on-the-job training (including apprenticeships), formal education, study programmes for adults which are not organized by firms, and the migration of individuals or families to adjust to changing job opportunities. Becker (1975) subdivides human capital investments into on-the-job training (general and specific training), schooling, knowledge about job opportunities, and health and working conditions. According to Blaug (1976, p. 5) the basic idea of the concept of human capital is that "people spend on themselves in diverse ways, not for the sake of present enjoyments, but for the sake of future pecuniary and non-pecuniary returns." An individual decides to invest in human capital if the present value of all future benefits as a result of the investment decision are at least as great as the present value of the costs due to the investment decision. However, this paper will not explain the investment decisions of individuals, but will rather consider the human capital of individuals or workers as a factor of production at the firm level.

This introduction will give a short overview of the material covered in the remaining sections. This material is summarized in diagram I. The left side of the diagram shows the three ways in which a firm can acquire human capital. A first form of human capital that can be used by the firm is the initial training of newly hired workers. Workers who enter the firm bring with them human capital acquired in their initial schooling or by working for a previous employer. Subsection 2.1 will consider why initial schooling increases the productivity of workers. Subsection 2.2 considers the initial schooling of workers as a factor of production, i.e. as an input factor for the production process, and tries to construct a measure for effective labour input. Subsection 2.3 models the impact of initial schooling on productivity and employment.

A firm can acquire human capital by recruiting new workers or by training its workers. Investment in training will be discussed in subsection 3.1. These investments can be either general or specific.

1. I would like to thank Andries de Grip, Hans Heijke and Lex Borghans for their helpful comments. 
Completely specific training is only of value for the firm the employee works in. Completely general training is equally valued by all firms (Becker, 1975). However, the accumulation of human capital is not necessarily related to planned investments, but can also take place through learning-by-doing. The difference between investment in training and learning-by-doing is that working time has to be sacrificed for formal training, whereas learning-by-doing is an inevitable by-product of working (Killingsworth, 1982). Time spent on working cannot be spent on training, i.e. they are substitutable, whereas working and learning are complementary. In diagram $I$ this is indicated by the arrow going from the label 'production function' to 'learning-by-doing'. As will be discussed in subsection 3.2, learning-by-doing can be an asset of the firm as an entity (for example goodwill), or may be embodied in the owners, managers or employees (Bowman, 1974). Subsection 3.3 also discusses the substitutability and complementarity between the various forms of human capital, such as initial schooling and training. However, a firm does not only accumulate human capital, it is also subject to the obsolescence of human capital (Gelderblom and De Koning, 1992a). The arrow in diagram I from the label 'production function' to 'obsolescence of human capital' indicates that the obsolescence of human capital accelerates if the production function changes due to technological diffusion. This will be discussed in subsection 3.4 .

Sections 2 and 3 treat human capital as an input factor for the production function. Diagram I also shows that human capital is an input factor for the production of research and development (see Mincer, $1984,1989 \mathrm{c}, \mathrm{d}$ for some links between human capital and technology). Higher education, in particular, is an important input factor for research and development (R\&D). R\&D in turn produces technological knowledge, which can also be acquired by learning-by-doing and spillovers from other firms. ${ }^{2}$ As diagram I shows, technological knowledge can again be an input factor (together with human capital) for the firm's own research and development. This relation represents an important feed-back mechanism, and has been widely used in endogenous growth theory (see for example Lucas, 1988, Romer, 1990, and Van Ewijk, 1993). The above relations will be discussed in section 4. Moreover, the diffusion of new technologies, i.e. the adaptation of new technologies (see also Bartel and Lichtenberg, 1987), is dependent not only on the technological knowledge available, but also on the stock of human capital of the firm. This will be discussed in subsection 4.1 and 4.2. Another relation shown by diagram 1 is that the change of the production function, as a result of the diffusion of new technologies, leads to a change in the demand for human capital because of capital skill and technology skill complementarities (Mincer, 1989c). This will be discussed in subsection 4.3.

To summarize, the firm uses human capital as an input factor in the production process. It can accumulate human capital by recruiting new workers with a particular level of educational attainment (section 2), by training or by learning-by-doing (subsections 3.1 to 3.3). However, human capital is lost by skill obsolescence (subsection 3.4). Moreover, human capital is an input factor for the production and diffusion of technological knowledge, and the firm demand for human capital is determined by the production technologies used by the firm and by the diffusion of new technologies (section 4). Section 5 will summarize the paper and draw some conclusions.

2. Section 4 will not make a separate analysis of the possibility of buying technological knowledge, but will treat the purchase of technological knowledge as a form of investment. 


\section{Initial schooling}

Firms can acquire human capital by recruiting new qualified workers. For this reason the initial schooling of the labour force, also referred to as initial education, ${ }^{3}$ will be the starting point of the analysis in our paper. Initial schooling stands for all kinds of education at primary, secondary and tertiary levels. Employers are generally unable to influence the outcome of the educational system for initial education because, apart from apprenticeship training, the government is primarily responsible for the initial schooling of the labour force. Thus, for an individual firm, both the average level and the distribution of initial education of the labour force is largely given, although at regional level, in particular, large firms or sectors of industry are evidently points of reference for the structure of initial vocational education.

This section deals with some simple consequences of the impact of initial schooling on both workers' productivity and the firm's demand for labour. Subsection 2.1 will briefly consider the relation between education and labour productivity according to human capital theory, screening theory and assignment theory. ${ }^{4}$ Five effects of education on productivity can be distinguished, i.e. the worker and the allocative effect, the signalling effect and two effects related to technological change, that is the diffusion effect and the research effect. The next subsection (2.2) will briefly discuss how the impact of education on productivity can be modelled in a production function. Finally subsection 2.3 , will formalise the relation between education on the one and productivity, wages and the demand for labour at the firm level on the other hand.

\subsection{Education and labour productivity}

The abundant research on the relation between workers' education and earnings shows that the average earnings of workers is strongly positively related to their level of educational attainment. However, human capital theory, screening theory and assignment theory all have different explanations for this empirical finding. Nevertheless, they have in common the assumption that (in general) workers' real wages equal their marginal productivities. This assumption is very useful since it is difficult to measure marginal productivities in physical terms. Therefore, in empirical research, differences in marginal productivities are usually measured by differences in real wages. As a result, it is very difficult to prove that earnings or real wages indeed reflect physical productivities (Woodhall, 1987b). Moreover, theories differ with respect to the question of why marginal productivities should increase with years of schooling, which is often taken as a proxy for the level of educational attainment of workers.

In human capital theory (for example Becker, 1975 and Mincer, 1974) the strong positive relation (on average) between education and earnings is causal: investment in human capital increases workers' productivity and therefore their future earnings. This is indicated by age-earnings profiles (see for example Blaug, 1970, Mincer, 1974, Pencavel, 1991), which show the relationship between earnings and age at different levels of educational attainment. It turns out that the wages of more educated workers are in most cases higher than those of less educated workers of the same age. The profitability for individuals' investment in initial schooling can be calculated by the net present value method, under

3. Schooling and education are used interchangeably. However, Pencavel (1991) states that education and schooling are not synonymous, because education takes place not only in schools, but also out of schools, i.e. in families, communities and work places.

4. Hartog (1991) uses 'assignment theory' as a synonym for 'allocation theory'. I prefer to use 'assignment theory' to prevent the reader from confusing 'allocation theory' and 'allocative effect' (see below). 
which the costs (tuition fees, earnings forgone due to not working) and benefits (higher future earnings) of education are discounted at a particular discount rate. Using this method, Mincer (1974) showed theoretically and empirically that the percentage increments in annual earnings are linearly dependent on absolute differences in years of schooling times the rate of return on one additional year of schooling. However, it is not clear to what extent investments in human capital cause earnings and productivity increases (see for a discussion Blaug, 1976 and 1985).

Inspired by human capital theory, Welch (1970) mentions two effects of education on productivity. He distinguishes between the worker and the allocative effect and argues that the effect of initial schooling depends on the production process in which the worker is involved. One would intuitively suppose that the more complex a production process is, the more can be gained by higher educated workers. With regard to the worker (or 'own productivity') effect, Welch (1970) assumes that firms produce only one good with the production factor education, and that other resources are given. The worker effect refers to the increased marginal productivity of education with respect to that particular good. Better or longer initial schooling means that the worker can produce more physical output. In other words, education increases the effective labour input from the hours worked. Thus, a better educated labour force is equivalent to a larger labour force. Moreover, the worker effect has analytically the same implications as labour-augmenting technical progress. Depending on the type of production function, the enhanced labour input may increase the productivity of other factor inputs as well (Pencavel, 1991). Lockheed (1987) gives an overview of a number of studies to test the hypothesis that higher levels of formal education increase farmers' efficiency. By computing a weighted average of productivity increases of several studies, he comes to the conclusion that farm productivity is increased by 7.4 percent due to a farmer's completing four years of elementary education rather than none. However, it is not clear whether the worker effect is solely responsible for the productivity increase.

Welch (1970) explains the allocative effect by stating that education increases the efficiency with which the input factors are allocated between alternative uses, because more educated workers are likely to be better informed about the contribution of each input factor to the output, and about the prices of input factors (see also Pencavel, 1991). Welch (1970) gives two examples of the allocative effect. If there is one fixed input factor to produce two goods, education may improve the total revenues of firms by means of better allocation of the input factor between the alternative outputs. Although the production process is technically efficient because the firm produces on the production possibility curve (expressed in physical units), workers have more knowledge of how to maximize the marginal value product (expressed in money units) of the input factor. Total revenues are maximized if the marginal value product of the input factor is equalized for all goods. It seems that initial education leads to an increased knowledge of the situation on the commodity markets. Another allocative effect is present if, apart from education as an input factor, purchased inputs are also included in the production function. If just one good is produced with two (or more) purchased inputs, education may also help to select the efficient quantities of inputs. In equilibrium the marginal value product of purchased inputs should equal the price of purchased inputs.

Ram (1980, p. 366) slightly extended the allocative hypothesis by stating: "Education generally has the effect of lowering the (marginal) costs of acquiring production-related information, and of raising the (marginal) benefits of such information." The reasons education might lower the marginal costs include better communications skills and the better contacts of more educated individuals. The reasons education might increase marginal benefits could include the greater capabilities of more educated 
individuals to apply the information received and to make better decisions based upon the available information. Ram (1980) stresses the role of the value of information for the allocative process within a firm. Initial schooling makes it possible to increase the amount of useful information. For that reason schooling is more valuable where the role of information is crucial, such as in dynamic and/or complex production environments. In static environments with a lot of routine tasks to be performed, information and thus schooling seems to be less relevant (see also Welch, 1970). Ram's empirical study reveals that the payoff from schooling of farm operators in Indian agriculture is higher than the payoff from schooling for hired workers. This supports the allocative hypothesis, because farm operators have relatively more allocative and management decisions to make. Ram's empirical results are confirmed by a number of empirical studies, as reviewed by Lockheed (1987). These studies lend support to the hypothesis that the payoff for farmers in a changing modernizing environment is higher than in a static traditional one.

However, alternative theories for human capital theory do not presuppose a causal relationship between education and productivity. In screening theory, educational institutions select students on certain personal characteristics by letting students pass or fail, giving grades for specific courses, determining the speed with which students complete a course of study, etc. Moreover, students sort themselves according to the fields in which they have comparative advantage. For example, a student tends to choose mathematics if his or her mathematical ability, relative to his or her verbal abilities, are larger than other students' mathematical abilities relative to their verbal abilities. ${ }^{5}$ There are, however, many versions of screening theory (see for example Winkler, 1987). Both Arrow (1973) and Spence (1973) state that the educational qualifications ('credentials') of workers on the job market are a signal for employers. One important assumption which they make is that the costs of acquiring education, for example forgone earnings, tuition fees and physical costs, are lower for individuals with higher productive abilities, because they need less time to acquire an educational credential. For this reason individuals with higher abilities will (on average) invest more time in education. ${ }^{6}$ Hence, educational credentials signal more productive workers. Employers, searching for indicators that may be correlated with productivity, use those credentials to sort out more productive individuals. This establishes an improved allocation of heterogeneous workers on the labour market and, hence, can lead to higher production for a firm (and the society).

Nevertheless, for both students and employers the reason for the positive correlation between education and productivity (or earnings) does not matter. An individual will invest in human capital as long as the marginal benefits (higher future earnings) exceed the marginal costs (earnings forgone by not working, or school fees). An employer screens individuals on their productive ability and offers a wage which reflects this ability. But for society as a whole, the question above does matter. According to screening theory the educational system merely signals the ability and potential productivity of applicants, but does not enhance the productivity of individuals. Screening by the educational system provides valuable information for employers with regard to workers' productive ability.

In Spence's model, as described above, education does not enhance productivity. This is called the 'strong' version of screening theory. Students' skills are not improved by schooling, since most of the

5. On the issue of comparative advantage, see Rosen (1978).

6. See also Becker (1975) and Hartog (1993) on this topic. Hartog (1993) shows that only under certain conditions will abler individuals undertake more schooling. 
skills required to be productive are learnt on the job. This is the principal difference between human capital and screening theory: the question of whether or not initial schooling increases the productive ability of individuals. "What is debatable is whether schools screen for some ex ante innate ability or for some ex post ability which includes the productivity-augmenting effects of education." (Winkler, 1987) Empirical research has found no evidence for the assertion of the 'strong' version of screening theory that education has no direct effect on productivity (Woodhall, 1987a). However, 'weak' versions of screening theory do not deny that education enhances productivity by providing knowledge and skills. Moreover, screening theory is complementary to human capital theory in that it states that educational qualifications also indicate the abilities, aptitudes and altitudes of individuals and that those are partly shaped and developed by the educational system. "The reason why the screening hypothesis is important is that it has focused attention on the precise way in which education or other forms of investment in human capital influence productivity, and has served as a reminder that education does far more than impart knowledge and skills." (Woodhall, 1987a, p. 24)

Similarly, in the labour queue model of Thurow (1975) the employer regards educational qualifications as a signal or screening device. Individuals on top of the labour queue are selected first by employers, because these workers have a higher trainability, which reflects a lower cost of training (see subsection 3.3). More highly educated individuals therefore get a higher position in the labour queue. Thurow stresses the selection process on the demand side of the labour market and assumes that employers regard jobs as the elementary demand side entities. Moreover, in Thurow's model job characteristics determine wages and marginal productivities. The assignment theory (for example Sattinger, 1993) combines the explanations oriented to demand side, as in Thurow's model, and supply side explanations such as the human capital model. It follows that marginal productivity is determined by both job characteristics and the level of education. Moreover, workers with a given education may be more productive in one job than in another. This feature of the assignment model emphasizes the importance of good allocation of workers for the total output of a firm or a country (see Hartog, 1988). Hartog (1992) finds evidence for the hypothesis that both the job level, measured on a scale of job complexity, and the level of education determine workers' earnings. Again, earnings are supposed to reflect marginal productivities. Thus, the screening or signalling function of education can lead to a better match of workers to a particular job, and therefore a higher productivity of workers in a firm. We call this the signalling effect of education.

The fourth and fifth effects of education on productivity are related to the faster rate of, respectively, technological diffusion and technological progress due to having more highly educated workers. The former effect is based on the Nelson-Phelps hypothesis and is called the diffusion effect. Nelson and Phelps (1966) state that "educated people make good innovators, so that education speeds the process of technological diffusion." Better educated workers are more able to adapt to technological changes and will introduce new techniques of production more quickly. Like Ram (1980), Nelson and Phelps (1966) stress the role of receiving, decoding and understanding information in performing a job. A higher level of education increases the ability to discriminate between more and less profitable innovations and reduces the uncertainty about investment decisions with regard to new processes and products. As a result, education increases the probability of that innovations will be adopted early. This was confirmed for U.S. farm operators by an empirical analysis of Wozniak (1987). Nelson and Phelps (1966) also point out that the faster the rate of technological change the more human capital is required and the higher the rate of return to education (see also subsection 4.2). This result is confirmed by Welch (1970) in a 1959 cross-sectional empirical analysis of agricultural farms. He finds that the wage of college 
graduates relative to less educated workers is higher in farms with higher research expenditures. Similarly, Bartel and Lichtenberg (1987) note that more highly educated workers have a comparative advantage in adopting and implementing innovations. They argue that a new technology initially raises the degree of uncertainty with regard to that technology. Both the accumulation of experience with a technology ${ }^{7}$ and a better educated workforce reduce the uncertainty. In particular, Bartel and Lichtenberg (1987) put forward the hypothesis that the relative demand for educated workers declines with experience with a new technology, which is approximated by the age of the capital stock. Hence, the benefits of education are smaller with increased experience, and so is the relative demand for highly educated labour. Bartel and Lichtenberg (1987) confirm their hypothesis in an empirical analysis with 61 U.S. manufacturing industries.

Finally, Pencavel (1991) refers to an effect of education on productivity that is related to technological progress. We will call this effect the research effect. Pencavel (1991) states that investments in higher education are usually accompanied by complementary public investments in R\&D. Many activities in higher education serve both research and instruction purposes. Moreover, R\&D activities at universities are often closely linked to those in research institutes and private industries (Jaffe, 1989). Section 4 will show that human capital is an important input factor for the production of R\&D. In turn, R\&D is a key factor for technological progress, economic growth and productivity growth.

\subsection{Effective labour input}

To analyze the effects of initial education on productivity, wage and labour demand, it may be valuable to make use of a production function. Griliches (1970) and Fallon (1987) $)^{8}$ mention different possible ways of

modelling the effects of education in a production function by a measure for effective labour. Consider the production function $f$ of a firm in a neoclassical environment:

$$
Y=f(L, \bar{K}) \quad ; \frac{\partial f}{\partial L}>0, \frac{\partial^{2} f}{\partial L^{2}}<0
$$

Variables $Y, L$, and $K$ refer to the total volume of production, the effective labour input, and the stock of physical capital respectively. The first and second order partial derivatives of output with respect to effective labour in equation (2.1) indicate that the marginal product of labour is positive but diminishing. When the stock of physical capital is constant the second order partial derivative is negative because of the law of diminishing marginal returns of labour. However, our aim is to consider the effects of initial education using a measure for effective labour. This measure can be constructed by first combining different types of labour and then differentiating between uneducated (or raw) labour and human capital. $^{9}$

With regard to the first method it is assumed, for simplicity, that initial education is either a good proxy (a screening device) for the joint effect of all other relevant determinants of effective labour or the only

7. Bartel and Lichtenberg (1987) refer to the standard learning curve to explain that, due to experience in working with a technology, i.e. learning-by-doing, production costs decline at a diminishing rate with cumulated output (see subsection 3.2).

8. See also De Koning, et al. (1990), in particular chapter 7 and 8.

9. Other possibilities mentioned by Griliches (1970) and Fallon (1987) concern the impact of education on the various parameters of a standard production function. 
determinant of effective labour (see Fallon, 1987). This means that one need not consider variables such as socio-economic background and gender. Fallon (1987) gives an overview of possibilities to combine the various educational categories $N_{\mathrm{i}}$ of workers in a firm into a single labour quality measure $L$. We can correct for human capital by adding up the various educational categories after weighting them for their mean wages. Weighting the educational categories by their mean wages assumes that real wages equal marginal productivities and that the relative marginal productivities of different labour categories are constant. The latter assumption implies that the various types of labour are perfect substitutes for each other, i.e. the elasticity of substitution between any pair of educational categories is infinite.

$$
L=\sum_{i=1}^{n} \bar{w}_{i} N_{i}
$$

Variable $w_{i}$ represents the real mean wage of labour type $i$ and also equals the marginal productivity of labour type $i$. However, the assumption of perfect substitutability of different types of labour seems to be rather unrealistic. To meet this difficulty, $L$ can also be calculated by combining the different educational categories into a constant elasticity of substitution function (CES) or into a Cobb-Douglas function. An example of the latter is given in equation (2.3).

$$
L=\prod_{l=1}^{n} N_{i}^{a_{l}}
$$

In a Cobb-Douglas function the elasticity of substitution of two labour categories is unity. Coefficient $a_{i}$ equals the optimal share of $N_{i}$ in total wages. ${ }^{10}$

One has to note that the ways of combining different types of labour into one measure of effective labour (labour quality) which have been described above assume that the ratio of the marginal products of any two types of labour is independent of the stock of physical capital. This assumption is called homothetic separability (Fallon, 1987). ${ }^{11}$ If the assumption is not met (see for example Griliches 1969, 1970), the input of physical capital in the production process does matter for the relative marginal productivities of labour and thus for the labour quality measure. In that case the input factors of the various types of labour cannot be aggregated into a single labour quality measure without correcting for the factor input of physical capital. Empirical studies such as those by Griliches (1969), Broer and Jansen (1989) and Hebbink (1992) do indeed suggest that physical capital has more complementarity with highly educated labour than with less educated labour. Moreover, the study by Welch (1970) which was mentioned above indicates that the marginal productivities of highly educated labour are relatively larger than those of less educated labour in agricultural farms with high research expenditures. These studies suggest that the condition of homothetic separability is not met with regard to either capital or research expenditures. However, the findings of these studies fit very well with both the allocative and the diffusion effect, because if production processes are more complex due to the use of other factor inputs or due to technological changes (which may result from R\&D expenditures, see subsection 4.2), then highly educated labour is more valuable for the production process of the firm than less educated labour. Similarly, human capital is more valuable for firms in a complex dynamic environment than in a simple static one.

10. This can be shown by differentiating to $N_{\mathrm{i}}$.

11. Note that this condition has consequences other than the assumption that the capital stock is fixed, since if capital stock is fixed and the total effective labour input increases, the ratio of marginal productivities may change. 
A second method for calculating the effective labour input is by distinguishing between human capital input per worker, $H$, and uneducated labour input ('raw labour') represented by the total number of workers, $N$. Human capital can be considered as a (non-observed) homogeneous substance measured by the sum of the differences between the mean wage of each educational category, $w_{i}$, and the mean wage of uneducated labour (for example a minimum wage), $w_{0}$, across all educational categories.

$$
H=\sum_{i}^{n} \frac{\left(\bar{w}_{l}-\bar{w}_{0}\right) N_{l}}{N}
$$

Here the effective labour input equals the number of workers times the amount of human capital per worker:

$$
L=N H
$$

We assume that $H$ is exogenous for both the firm and the workers, since the quality of the type of workers required by the firm is 'produced' by the educational system. Griliches (1970) shows that when effective labour is an input factor in a production function one is unlikely to be able to distinguish between the second method of effective labour input and the perfect substitution version in equation (2.2). ${ }^{12}$ In the following model the second method is used. In order to keep the analysis as simple as possible, different types of labour are not distinguished. Therefore we assume that a firm has a demand for homogeneous workers with human capital per worker of $H$. The purpose of the analysis is to show the effect of, firstly, an increase in the supply of workers with a fixed level of initial education and, secondly, an increase in the quality of initial education enjoyed by those workers.

\subsection{A partial labour market model}

Labour demand and supply will be considered at the firm level in a partial framework. It is assumed that the firm's demand for workers encounters the supply of homogeneous workers in a particular segment of the labour market. Moreover, the labour demand is a derived demand, i.e. it can be derived from the production function and from supply and demand in a market for homogeneous goods. Furthermore, from standard labour economics we know that the supply of labour, whether expressed in number of workers or in number of hours, is dependent on the wage that is offered (see for example Ehrenberg and Smith, 1993): the labour supply curve is upward sloping with respect to wages. ${ }^{13}$ This implies that the firm is confronted with a given market relationship, in a particular segment of the labour market, between the real wage $w$ per worker and the supply of $N$ homogeneous workers. ${ }^{14}$ Equation (2.6) in fact represents the inverse function of the common labour supply curve at the firm level.

$$
w=w(M)
$$

If the firm has some monopsonistic power on the labour market segment, the real wage increases with the demand for labour. This implies that $\partial w / \partial N>0$, i.e. the labour supply curve, slopes upwards.

12. Moreover, in a Cobb-Douglas production function the effects on total production of either an increase of human capital or labour-augmenting technical change are the same (see subsection 4.2).

13. The part of the labour supply curve which bends backward is not considered here.

14. Here the use of the term 'real wage' is not completely correct as it represents the nominal wage divided by the product price of the firm instead of the nominal wage divided by some general (macroeconomic) price index. 
The real wage per worker is constant if there is perfect competition in the labour market segment on which the firm demands labour. This implies that $\partial w / \partial N=0$, i.e. the labour supply curve is horizontal in a labour market segment with perfect competition.

The profit function $\pi$ of the firm is given by

$$
\text { II }=P Y-N W-C
$$

where $P$ is the price per unit of $Y, W$ is the nominal wage per worker and $C$ is the total fixed costs. The firm can maximize profit $\pi$ by choosing the optimal effective labour input, here the optimal number of workers. ${ }^{15}$ We assume that the amount of human capital per worker $H$ is fixed for the time being. Profit maximization follows by differentiating $\pi$ with respect to $N$ and setting the result equal to zero.

$$
P \frac{\partial Y}{\partial N}+Y \frac{\partial P}{\partial Y} \frac{\partial Y}{\partial N}-W-N \frac{\partial W}{\partial N}=0
$$

which can be rewritten as

$$
\frac{\partial Y}{\partial N}=\frac{W}{P} \frac{1+1 / \varepsilon_{W}}{1+1 / \varepsilon_{P}}
$$

where

$$
\begin{gathered}
\varepsilon_{W}=\frac{\partial N}{\partial W} \frac{W}{N} \\
\varepsilon_{Y}=\frac{\partial Y}{\partial P} \frac{P}{Y}
\end{gathered}
$$

From equation (2.9) it follows that the marginal product of labour equals the real wage corrected for the wage elasticity of labour supply shown by equation (2.10) and the price elasticity of demand shown by equation (2.11). The firm can determine the level of marginal productivity by choosing the number of workers $N$, since the higher the number of workers the lower the marginal productivity per worker will be. This is a result of the condition added to equation (2.1), stating that the first order partial derivative of output with respect to labour is diminishing. The level of employment at which equation (2.9) is satisfied maximizes the profit of the firm, so that this level of employment represents the labour demand of the firm.

In the case of perfect competition on both the labour and product markets, the elasticities defined above approach infinity and therefore the marginal productivity of labour equals the real wage. In this situation the firm is a price (or wage) taker on both markets. In other cases the real wage and the marginal productivity will probably not be equal. For example, if the firm has monopsonistic power on the labour market and hence is a wage maker on the labour market, it will be confronted with an upward sloping labour supply curve. Therefore, the slope of the marginal labour cost curve will be greater. As can be concluded from equation (2.9), the marginal cost of labour will then exceed the real wage.

15. The number of working hours per worker is assumed to be constant. 
However, to analyze the impact of initial schooling on productivity, wages and labour demand we assume that the firm operates in a perfectly competitive environment in both the labour and the product market. The results of our analysis do not change much when less competitive market forms are chosen. Under perfect competition, equation (2.9) changes into equation (2.12). The real wage is represented by $w$.

$$
\frac{\partial Y}{\partial N}=\frac{W}{P}=W
$$

Equation (2.12) is represented by curve $D^{F}$ in figure 1, showing the firm's demand for labour in a particular labour market segment, for example engineers. The curve reflects the increase in the level of employment in the firm when the real wage costs decrease. The marginal productivity equals the real wage in case of perfect competition. The curve is downward sloping due to the law of diminishing marginal returns (see equation (2.1)). ${ }^{16}$ The supply of engineers at the firm level is given by curve $S^{F}$, which reflects equation (2.6). The supply curve of labour is horizontal because the real wage elasticity of labour supply approaches infinity, i.e. the firm is a price (wage) taker on the labour market segment for engineers.

The equilibrium wage of engineers is determined on the labour market for engineers as shown in figure 2 , below. Curve $D$ and curve $S$ show the aggregate demand and supply in this labour market segment, respectively. The aggregate demand and the aggregate supply of engineers equal the sum of, respectively, the demand and the supply curves of all firms (horizontally aggregated). According to one of the Hicks-Marshall laws of derived demand (see, for example, Ehrenberg and Smith, 1993), the wage elasticity of demand for engineers tends to be low when the price elasticity of demand for the good being produced is low. If the price elasticity of demand for good $Y$ at sector level is nil (perfectly inelastic), the wage elasticity of demand for engineers is also nil. The supply of engineers is upward sloping because the higher the wages of engineers, the more attractive it is for individuals to work as engineers (relative to other occupations). It follows that the level of employment in the labour market segment is $N^{*}$ number of workers, who are rewarded at the real market wage $w^{*}$. At this real wage the firm employs $N^{F}$ workers (figure 1).

16. In the long run the demand curve is downward sloping due to the output (scale) effect and/or the substitution effect. The former effect refers to the increase in product demand due to lower wage costs. This may result in a lower product price and a higher level of production. The latter effect refers to the substitution of capital for labour due to lower relative factor costs of labour. Both effects increase the demand for labour in the long run. Here we will not consider these long term effects on the demand for labour. 
Figure 1

Labour demand and supply for engineers at the firm level, given perfect competition on the labour market

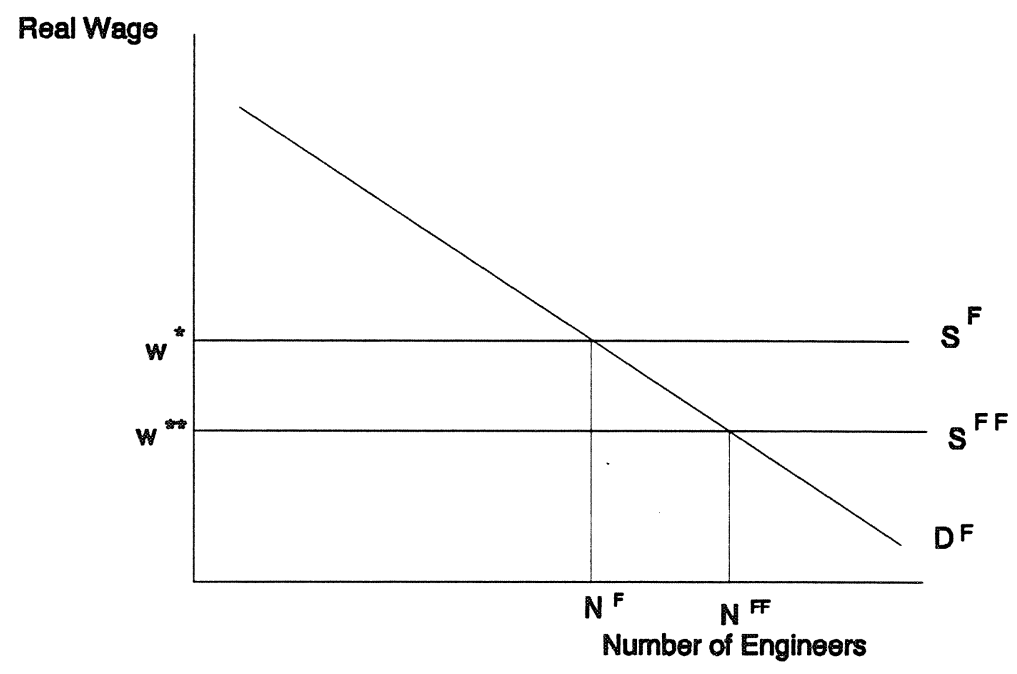

We will now analyze the consequences of (i) an increase in the number of workers with a particular type of initial education, such as engineers, and (ii) an increase in the human capital per engineer. The former induces a downward shift of the labour supply curve, whereas the latter may induce whether an upward or a downward shift of the labour demand curve.

Figure 2

Labour demand and supply in the labour market for engineers

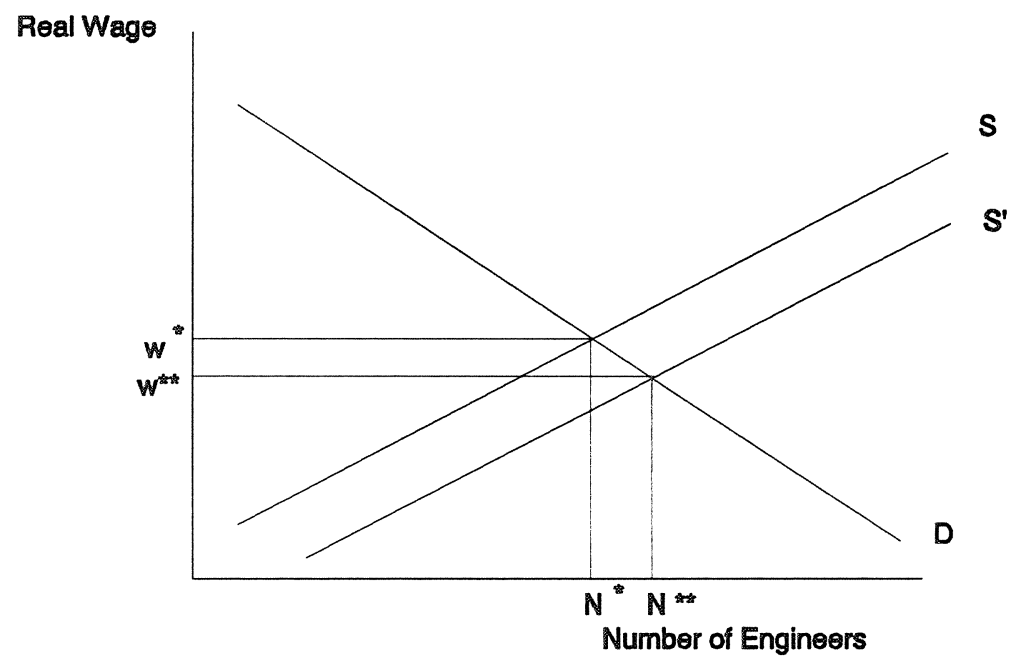




\section{(i) Shifting the labour supply curve}

Suppose that the supply of engineers, $N$, is increased, perhaps by a government labour market programme. The aggregate supply curve of engineers is shifted to the right (curve $S^{\prime}$ in figure 2 ) which leads to a decrease in the engineers' marginal productivity and equilibrium wage, to $w^{*}$. On the other hand, the larger supply of engineers increases the equilibrium employment to $N^{\mathrm{FF}}$. The firm will be confronted with a lower wage for engineers (see equation (2.6)). This implies that the horizontal labour supply curve at the firm level shifts downwards (see curve $\mathrm{S}^{\mathrm{FF}}$ in figure 1 ) and the new equilibrium point at the firm level is represented by $\left(W^{*}, N^{\mathrm{FF}}\right)$. This can be illustrated by using equations $(2.1),(2.5)$ and (2.12) to derive the following equation:

$$
w=\frac{\partial Y}{\partial N}=\frac{\partial f(L)}{\partial N}=H \frac{\partial f(N H)}{\partial N H}=H f^{\prime}(N H)
$$

If the real wage decreases from $w^{*}$ to $w^{*}$ due to the outward shift of the supply curve in the labour market segment for engineers (figure 2), it follows that the firm faces an exogenous decrease in the real wage to $w^{\prime \prime}$. The firm finds itself temporarily at point $\left(w^{\prime \prime}, N^{F}\right)$. Since at this point the real wage is lower than the marginal productivity (represented by curve $D^{F}$ in figure 1 ), it will be profitable for the firm to increase the number of engineers $(M)$ employed. Due to the law of diminishing returns of labour, the marginal productivity of labour decreases as the firm employs more engineers, i.e. $\partial f / \partial N<0$. The firm will stop employing new engineers when the marginal productivity of an engineer equals the new (lower) real wage level $w^{*}$. This implies that the marginal productivity decreases from $w^{*}$ to $w^{*}$ along curve $D^{F}$. Thus, due to the increase in the supply of engineers, the real wage of engineers falls, whereas the employment level increases to $N^{\mathrm{FF}}$. The magnitudes of these changes are dependent on the wage elasticities of the demand and supply of engineers. If, for example, the demand for engineers is perfectly inelastic (i.e. a vertical demand curve), then the increase in the supply of engineers is expressed entirely in a fall in the real wage level, without changing the level of employment. If, on the other hand, the demand for engineers is perfectly elastic (horizontal demand curve), the increase in the supply of engineers is entirely expressed in a rise in the level of employment, without changing the real wage level.

\section{(ii) Shifting the labour demand curve}

Suppose that the amount of human capital per engineer, $H$, increases. Since we want to concentrate only on the demand side of the labour market we assume, for the time being, a perfectly elastic supply of labour in the labour market segment for engineers (i.e., a horizontal labour supply curve). Moreover, we assume that the increase in human capital per engineer is the result of improved efficiency in the educational system, without increasing the costs of that education for the engineers (their investments). ${ }^{17}$ These assumptions imply that the real wage per engineer, $W / P=\boldsymbol{W}^{*}$, does not change. The next equation, which is in fact similar to equation (2.13), illustrates two opposing effects which follow from the increase in the human capital per engineer. To indicate these two effects, the variable $H$ is written with subscripts 1 and 2 .

First, each engineer is more productive for the same (fixed) wage as before, i.e. $w^{*}$, as a result of the increase in the human capital per engineer, indicated by an increase of $H_{1}$. Since the real wage is fixed,

17. For this reason the amount of human capital per worker $H$ is not included in equation (2.6). 


$$
w=\frac{\partial Y}{\partial N}=H_{1} f^{\prime}\left(N H_{2}\right)
$$

the marginal productivity will be temporarily larger than the real wage. To re-establish equilibrium, more labour has to be employed, i.e. an increase in $N$, at the same real wage $w^{*}$, which lowers the marginal productivity of labour according to the law of diminishing returns. This results in a shift of the labour demand curve to the right, which is shown in figure 3. Second, more human capital per engineer, $H_{2}$, decreases the number of engineers $N$ needed to achieve the same level of effective labour input (and hence production). In other words, $\mathrm{N}$ and $\mathrm{H}_{2}$ are substitutes in the production function. The decrease in the number of engineers needed shifts the labour demand curve to the left. Of course, $H_{1}$ and $H_{2}$ represent the same variable $H$, and the strength of each of the two effects depends upon the specification of the production function. It can be shown that, given a Cobb-Douglas production function, the first effect, that is the productivity effect, will always be stronger (given the above assumptions and given the stock of physical capital) than the second, the substitution effect, so that the labour demand curve shifts to the right. ${ }^{18}$ In that case the net effect of an increase in the human capital per engineer is a rise in the level of employment at the same real wage level.

Figure 3

A shift of the labour demand curve at the firm level

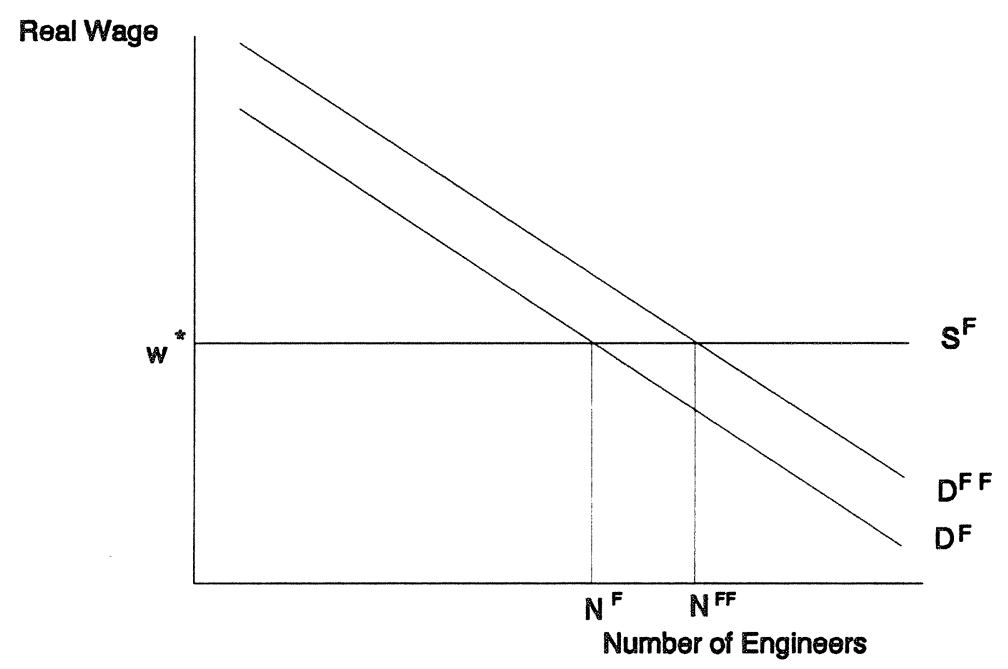

However, if the labour supply curve in the labour market segment for engineers slopes upwards (the slope depending on the elasticity of the labour supply), the rise in employment levels is less, whereas the real wage increases. Given perfect competition in the labour segment for engineers, the labour supply curve at the firm level is still horizontal. However the labour supply curve at the firm level shifts upwards if the equilibrium wage in the labour market segment for engineers rises. With a perfectly inelastic labour supply (i.e. a vertical labour supply curve) the increase in human capital (education) per

18. For a proof see appendix $B$ at the end of the paper. 
engineer would be completely passed on to an increase in the real wage per engineer, without any change in the level of employment.

\section{Training, learning and skill obsolescence}

In section 2 the quality of labour supply on the external labour market was treated as an important exogenous variable when firms want to hire new workers. Naturally we also have to consider various forms of human capital accumulation at the firm level, such as training and learning-by-doing. These different forms will be discussed by means of diagrams II and III, in appendix A. Subsection 3.1 deals with the training of employees in a firm. Subsection 3.2 considers the consequences of learning-bydoing for human capital at the firm level. Subsection 3.3 analyses some issues with regard to the substitutability and complementarity between different types of education and training. Finally, the human capital stock of the firm diminishes due to skill obsolescence. This will be treated in subsection 3.4 .

\subsection{Investment in training}

This subsection will begin by defining investment in training and learning-by-doing. Then different kinds of training will be classified according to their external or internal character on the one hand and, on the other hand, their formal or informal character (see diagram II in appendix A). Moreover, Becker (1975) has made an widely-used distinction between general and specific training. The theoretical background of the distinction between general and specific training is particularly useful in treating some recent empirical issues related to training. These issues are sharing, productivity and wage growth, labour turnover, under-investment in training and firm size.

\section{Distinguishing between training and learning}

To introduce our concepts of training and learning, we want first to refer to the definition of on-the-job training in standard textbooks on labour economics, (such as Ehrenberg and Smith, 1993), which divide on-the-job training into formal training, informal training and learning-by-doing. This definition makes it possible to distinguish between skills that are learnt by sacrificing working time for training time, and skills that are learnt by repeatedly fulfilling tasks without any loss of productivity. Killingsworth (1982) calls the former way of generating skills 'investment in training', the latter 'learning-by-doing'. These are alternative forms of human capital accumulation. The difference is that training requires an investment decision by the employee and employer, whereas learning-by-doing occurs as an inevitable by-product of working, without any investment decision. However, training can occur either in a formal training programme or informally, on-the-job. Thus employees, in being supervised, in consulting colleagues or books, or in learning to understand how work processes are carried out, are engaged in some form of training. However, the dividing line between acquiring skills through working in a job, i.e. learning-bydoing, on the one hand, and informal training on the other is rather thin, because informal types of training often go hand-in-hand with being at work and producing something, i.e. learning-by-doing. According to the standard textbooks of labour economics, both fall within the definition of on-the-job training. The major difficulty in distinguishing informal investment in training from learning-by-doing is the increase in job-related skills with experience or age. We will briefly return to this point in subsection 3.2. 
New workers recruited by firms almost always have to learn additional skills they have not acquired during their initial education or previous jobs. Often these skills are firm-specific, i.e. they can only be learnt on-the-job within a particular firm. Bowman (1987) discusses the somewhat confusing range of definitions of on-the-job training in the context of human capital investment theory. ${ }^{19} \mathrm{He}$ first mentions training in the narrow sense, i.e. 'organized instruction in the work place', some examples of which are described in the bottom right-hand part of diagram II. Training in the broader sense encompasses all forms of job-related training, including formal instructional programmes, either within or outside the firm. Both forms of formal training are described in the upper part of diagram II. However, we will not regard external formal training (the top left-hand of diagram II) as on-the-job training (see below). Apprenticeships are a special form of training within the firm (see the top right-hand part of diagram II). They are often sponsored by the government, although this is dependent on the educational system of a country.

The wide scope of definitions of training causes serious difficulties in comparing training data from different countries, so that the empirical research on training has to be interpreted carefully. It seems that surveys which consider only formal company training programmes generate relatively less disparate statistics (OECD, 1991, chapter 5). Lynch (1992) gives an example of empirical research on formal training programmes. She uses longitudinal data from the National Longitudinal Survey Youth cohort (NLSY), which distinguishes between formal on-the-job training (i.e. formal training within the company, see the top right-hand part of diagram II), ${ }^{20}$ formal off-the-job training (i.e. formal training outside the firm, see the top left-hand part of diagram II) and apprenticeships (see the top right-hand part of diagram II). The training programmes in question lasted at least four weeks. Training programmes lasting less than four weeks and informal on-the-job training are assumed to be captured by a 'tenure on the job' variable. Another survey of training programmes is conducted by the Central Bureau of Statistics of the Netherlands (CBS, 1992). It divides formal company training programmes into formal on-the-job training ('bedrijfsopleidingen', see the top right-hand part of diagram II) which is open only to the workers of a particular firm and formal off-the-job training ('externe opleidingen', see the top lefthand part of diagram II). However the CBS definition contains no minimal duration for the training course, and it excludes apprenticeships.

\section{Theoretical background}

Now we turn to some theoretical issues of training at the firm level. According to human capital theory, the decision to invest in training is based on a cost-benefit analysis. Training is an investment in workers which raises both current training costs and future benefits, in the form of increased marginal productivity of workers. Firms and workers may incur training costs such as (Ehrenberg and Smith, 1993):

- the costs of the trainers in a formal training programme or in a less formal training situation (for example a demonstration);

- the costs of materials consumed during the training process;

- the opportunity costs of the workers' time devoted to training rather than to production activities.

\footnotetext{
19. In fact he does not consider learning-by-doing.

20. Learning-by-doing and informal training are not included in the definition of on-the-job training in this survey.
} 
The following example illustrates the consequences for the firm of training workers. ${ }^{21}$ Consider a firm that operates in a commodity market with perfect competition, i.e. in which product prices are given. Suppose that we distinguish just two periods: the initial period 0 during which the worker is trained and period 1 after the training period. Let us first assume that workers are paid according to their marginal productivities. All costs and benefits are expressed in real terms. The potential marginal productivity in the absence of any training is represented by $M P^{\circ}$. The marginal productivity decreases to $M P_{0}$ if the worker is participating in a training programme. Suppose that total training costs $C$ in the initial period consist of direct training outlays $k$ per worker (costs of the trainers and costs of materials) and the opportunity costs $M P^{*}-M P_{0}$ per worker (forgone production as a result of time spent on training instead of working). We noted earlier that training costs are an investment, because they raise the future marginal productivities of workers. The marginal productivity after training is given by $M P_{1}$. Figure 4 shows the relationship between the above productivities.

We assume that real wages are determined at sector level. This implies that a perfectly competitive firm is faced with a horizontal labour supply curve for both trained and untrained employees. Furthermore, future costs and benefits have to be discounted using the externally given discount rate $r$. For the initial period we have

$$
N C_{0}=w_{0}+k-M P_{0}>0
$$

where $N C_{0}$ represents the firm's net cost of training during the initial period, $w_{0}$ represents the real wage received by the employee in period 0 and $k$ represents the direct training outlays in period 0 .

Figure 4

Training, marginal productivities and labour demand

(Present Value of) Marginal Productivities

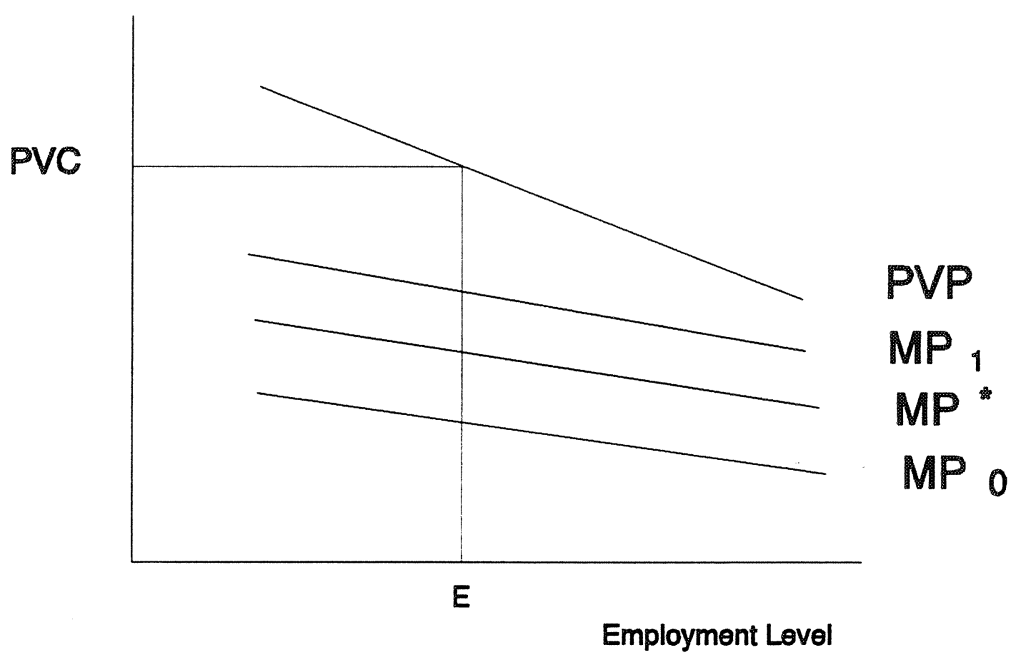

21. The analysis draws heavily on Becker (1975) and Ehrenberg and Smith (1993). 
For the period after training we have

$$
N B_{1}=\frac{M P_{1}-w_{1}}{1+r}
$$

where $N B_{1}$ represents the firm's net benefits of training in period 1 and $w_{1}$ represents the real wage received by the employee in period 1 . If a firm maximizes its profits then net costs equal net benefits

$$
w_{0}+k-M P_{0}=\frac{M P_{1}-w_{1}}{1+r}
$$

We can determine the two-period employment level $E$ of the firm by setting the present value of marginal productivities (PVP) equal to the present value of wage and training costs (PVC). Like the oneperiod labour supply curve, the PVC is horizontal. The equation for the PVP can be obtained by rewriting equation (3.3) to

$$
M P_{0}+\frac{M P_{1}}{1+r}=w_{0}+k+\frac{w_{1}}{1+r}
$$

where the left-hand side and the right-hand side represent $P V C$ and PVP, respectively. The equalization of $P V C$ and $P V P$ is also shown in figure 4 by the uppermost line. If total training costs $C$ (i.e. the sum of direct training outlays and opportunity costs, see above) are substituted for the direct training outlays $k$, equation (3.4) changes into

$$
M P^{*}+\frac{M P_{1}}{1+r}=w_{0}+C+\frac{w_{1}}{1+r}
$$

\section{General and specific training}

The above analysis helps us to explain the different consequences of general and specific training. Becker (1975) paid much attention to the differences between general and specific training. Completely general training increases the marginal productivity of employees by the same extent in all firms, whereas completely specific training only increases the marginal productivity of employees in the firm in which they are working, and has no effect on their marginal productivities in other firms. Bowman (1987) explains the difference between general and specific training by pointing to the complete portability of general human capital and the complete non-portability of specific human capital. However, company training or on-the-job training most often has both general and specific components (Becker, 1975). For example, the specialized training of pilots in the armed forces is easily portable to the civilian airlines, and so is termed general training.

Ritzen (1991) uses another definition of general and specific training, using the concept of transaction costs: "the category of specific training can be defined to include all those types of training for which the expected benefits of moving to another firm are not sufficient to offset the transaction costs of a move." (Ritzen, 1991, p. 189) This definition makes it possible to understand that circumstances other than the nature of training itself can be important. For example, training in a firm that is situated in a thinly populated region with low economic activity will be more specific than the same company training in a region in which similar firms are established. Furthermore, training in large firms tends to be more specific than the same training in smaller firms, because internal labour markets are probably better 
developed within large than within small firms. The larger the firm, the higher the transaction costs when workers who enjoyed training want to switch to another firm. We will return to the relation between training and the size of the firm below.

If skills are portable to other firms and the supposition of perfect competition holds, a firm will not be willing to pay for the cost of training (in either forgone earnings or direct outlays). This can be easily deduced from equations (3.1), (3.2) and (3.3). If the skills are completely portable, the firm that provides general training to the employee must pay a wage that reflects the employee's marginal productivity. If not, the employee will quit, since other firms are willing to pay according to his or her marginal productivity. So in the case of general training, the net benefits of the firm in period $1\left(N B_{1}\right)$ are zero. This implies that firms do not offer general training, so the costs of general training must be paid by the employees during their training time, i.e. in period 0 . Given the equality of net costs and net benefits in the two-period model indicated by equation (3.3), the net costs in the initial period $\left(N C_{0}\right)$ will also be zero. From equation (3.1) we can infer that

$$
w_{0}=M P_{0}-k
$$

Moreover, in the case of general training, employees pay not only for direct training outlays, but also for the forgone earnings due to spending time on training instead of working. This is shown by equation (3.7).

$$
w_{0}=M P^{*}-C
$$

As before, $M P^{*}$ indicates the marginal productivity without training.

In the case of completely specific training, the skills gained are not portable to other firms. The marginal productivity of the employee in other firms is still $M P^{*}$. The employee's marginal productivity in the firm that provided the specific training equals $M P_{1}$. If we first assume that the employee pays for all training costs in period 0 , as with general training, then equations (3.6) and (3.7) hold. Because the employee pays all costs of specific training, he ${ }^{22}$ will also collect the returns from the investment in specific training, i.e. $w_{1}$ equals $M P_{1}$. This implies that nothing is left for the employer. This does not differ from the situation with general training. However, because the firm has no incentive not to fire the employee (as with general training), the employee has a problem. In contrast to the situation with general training, in this case he can only earn his return on investment in the firm in which he enjoyed the specific training, because these skills are not portable to other firms.

Now assume that the firm pays for all training costs in the initial period and collect all returns in the next period. The employee will be paid according to his marginal productivity in the absence of training, $M P^{*}$, before and after training. His wage will not differ from the wage that he could get elsewhere, i.e. the market wage, so there will be no incentive for the employee to stay with the firm. In other words, he could, for whatever reason, easily quit. If the employee quits, the firm loses the opportunity to earn a return on the investment and is left behind with a net loss. Thus if either the firm or the employee pays all the costs of specific training, each would have to fear that the other party might terminate the labour contract. A solution lies in sharing the costs and returns for training between the firm and the employee. If both parties share the training costs they have an incentive to preserve the contract in order to earn

22. The use of 'he' or 'his' stands for either a male or a female employee. 
the return on investment. This implies for the wage in period 0

$$
\left(M P_{0}-K\right)<w_{0}<M P^{*}
$$

which is the same as

$$
\left(M P^{*}-C\right)<w_{0}<M P^{*}
$$

If the costs are shared, both the firm and the employee prefer a wage in period 1 that is above $M P^{\circ}$ and below $M P_{1}$ :

$$
M P^{*}<w_{1}<M P_{1}
$$

Equation (3.10) implies that, after sharing the costs of specific training during the investment period, the firm and the employee also share the benefits of specific training.

The above analysis of specific training has been formalised by Hashimoto (1981). However, he allows for uncertainty about the marginal productivity of the worker's specific human capital both in the firm and in an alternative employment situation. This uncertainty reflects errors in predicting market conditions. Given the density functions of expected values of the worker's real productivities inside and outside the firm, Hashimoto (1981) clearly shows that the sharing ratio, i.e. the worker's share in the cost of investment, affects both the dismissal and quitting probabilities and the expected net gains of the employer and employee. With regard to sharing the return to investment he remarks that "quits and dismissals produce external effects by preventing the parties from capturing the full return to investment. The worker is fully aware that the larger the share he claims, the greater is the probability of dismissal. The employer is just as aware that the larger the share he claims, the greater is the probability of quit." Both parties take into account the quit and dismissal probabilities of the other party. The higher the probability of a dismissal, the lower the worker's share of the costs. The higher the probability of a quit, the lower the employer's share of the costs. Both parties maximize the sum of their net gains by choosing the sharing ratio and the amount of specific human capital invested. Hashimoto (1981) concludes, like Becker (1975), that the sharing ratio is equal to the ratio of the worker's expected return to the total expected return (i.e. to the sum of the worker's and employer's expected returns).

Hashimoto's analysis also confirms an important conclusion of Becker (1975) that specific training raises a worker's wage profile, which is above his marginal productivity in the investment period but is below his marginal productivity during the post-investment period. Only with general training, when the worker pays all the costs of training, does the wage reflect the marginal productivity in the post-investment period. This implies that a worker's wage profile during his life-time is expected to be steeper with general than with specific training (see also Bowman, 1974).

\section{Productivity growth and sharing}

We will now discuss some empirical work relating to the above analysis. Mincer (1989b) and Bartel (1991a) note that most studies observe a positive relationship between training and wage growth at the individual level. Moreover the result stated above, that general training has a larger effect on wage growth than specific training, is empirically confirmed for newly hired employees by Bishop (1991). According to Bartel (1991b) the results of many of these studies are regarded as evidence for the positive impact of training on labour productivity. This makes it impossible to analyse how the cost of 
training are shared, since sharing the costs and benefits of specific training causes wages to differ from marginal productivities. However, Barron, Black and Loewenstein (1989) distinguish productivity increases from wage increases. In their study productivity was measured by asking the employer for a rating of the productivity of particular workers. They measure the effects of hours of training for recently hired workers on both productivity and wage increases, using a rather broad definition of on-the-job training which includes formal training, informal individualized training by supervisors and co-workers, observation by the new employee of other workers and the time spent on job orientation. Their empirical research shows the significance of training by pointing out that approximately $30 \%$ of the time of newly hired employees during their first three months of employment is used for on-the-job training activities. They find that a $10 \%$ increase in training is associated with a $3 \%$ increase in productivity growth and a $1.5 \%$ increase in wage growth. If the sharing of training costs mirrors the sharing of returns to training, this implies that workers share the costs of training equally with employers, given the assumption that all training is specific.

However we have to be careful with this interpretation for two reasons. Firstly, it is not clear to what extent the training received is specific or general. The theoretical analysis above suggested that workers pay for all the costs of general training themselves, which has direct consequences when measuring the sharing ratio of specific training. Secondly, empirical studies that use a technique similar to that used by Barron et al. (1989) find different sharing ratios. Bishop (1991) uses the same data set, whereas Groot (1993a) uses a Dutch data set on formal training courses. They find that the impact of training on the average wage growth is less than a fifth and less than a quarter, respectively, of the average productivity growth.

We are especially interested in the effects of training on the productivity level of the firm. However, according to Bartel (1991b) "too much research on the effects of training has been done at the individual level and not enough at the organizational level." Bartel's empirical study reveals that employee training programmes increase the growth in labour productivity of businesses ${ }^{23}$ in the manufacturing sector significantly. Businesses that were below their expected productivity levels (relative to other businesses) in 1983 implemented training programmes which resulted in significantly higher rates of labour productivity growth between 1983 and 1986. Using the Cobb-Douglas production function as in equation (3.11), Bartel (1991b) finds an independent and significant impact of training on the productivity level. The training variable was measured by a dummy, $D$, indicating whether or not the business had a formal employee training programme. The symbol $\tau$ represents the increase in productivity as a result of the training programme, and $\alpha$ and $\beta$ represent constant parameters. The other variables are the same as those used in section 2 . Moreover, the human capital variable of section $2, H$, here equals $1+\tau D$, while the amount of effective labour, $L$, equals $N(1+\tau D)$.

$$
Y=A(N(1+\tau D))^{\alpha} K^{\beta}
$$

The rate of productivity growth between 1983 and 1986 was at least $17 \%$ higher for businesses that implemented employee training programmes. Bartel (1991b) concludes that "the implementation of formal employee training programs can enable businesses that are operating at below-expected level of labor productivity to eliminate this gap."

23. A business corresponds here to either a firm or a division of a firm. 


\section{Sharing and turnover}

Another implication of the above theoretical analysis of Becker (1975) and Hashimoto (1981) is that sharing the costs of specific training reduces quits and dismissals. Mincer (1989b) mentions some studies which confirm the so called 'duality hypothesis', which states that both a steeper worker's wage profile (see above) and a lower turnover rate result from more training. Also Mincer (1989b) notes that lower turnover is accompanied by a reduction in the incidence of unemployment among workers who receive training, as almost half of labour turnover leads to unemployment. As Becker (1975) points out, workers who have enjoyed specific training have a lower chance of being dismissed if the firm is faced with a decline in the demand for its products, because the wages paid to those workers are less than their marginal productivities during the post-investment period. Thus, a shift of the firm's labour demand curve to the left, assuming given wages, does not immediately cause the dismissal of those workers.

Of course, this result does not hold for workers with general training, because (following Becker, 1975) they are paid according to their marginal productivities. Moreover if workers who have enjoyed a lot of specific training quit, this is very costly for both the firm and the workers. The return to investment in specific training will be at least partly lost with labour turnover. On the other hand, workers who have enjoyed more general training can relatively easy increase their wage by searching for better jobs. ${ }^{24}$ For these reasons turnover rates will be lower in firms or sectors that require relatively much specific training. However, we have to be aware that this mechanism also works the other way round, i.e. high expected rates of dismissal or quit and consequently a high turnover rate and a low average tenure decrease the incentive to share in the costs of specific training.

\section{Under-investment in general training and turnover}

The theoretical analysis above reveals also that firms are not willing to pay for general training. It follows that workers have to pay for it, e.g. by accepting a wage loss. Low liquidity and imperfect capital markets make it very difficult for the employee to borrow for investments in general training, which may lead to under-investment in general training. Another explanation for under-investment is offered by Ritzen (1991). According to him the under-investment is caused by the high risk associated with the returns to general training, which is empirically confirmed by some studies he mentions. Ritzen (1991) remarks that the high level of uncertainty as to the future returns when investing in training influences the training decisions of workers more than those of employers. This is caused by both the higher risk aversion of workers and their more limited means of pooling (diversifying) the risks, as compared to firms.

However, Ritzen (1991) notes that there is ample empirical research to show that employers do share in the costs of general training, for example Bishop (1991) and Hill (1991). If employers do indeed pay an important share of the costs of general training, then the empirical research contradicts the results of Becker's theoretical analysis. At the same time the argument that there is under-investment in general training is weaker, because employers seem also to invest in general training. Ritzen argues that this may be related to the earlier mentioned transaction costs of changing jobs. The higher the transaction costs for the worker if he quits, the more the firm is willing to pay for general training. The so-called complementarity hypothesis is another explanation which he mentions. This hypothesis implies that it

24. Note that investment in (costly) job searching is also regarded as a human capital investment (Becker, 1975). 
may be profitable for firms to invest in general training because it enhances the efficiency of specific training. A worker will not switch to another firm as long as his share of the return in general and specific training is larger than the full return on his general training ${ }^{25}$ if he switches to another firm.

Katz and Ziderman (1990) show that the predictions of Becker's model are also reversed if informational asymmetries are assumed. The employer may not be certain about the real amount of general training the applicant enjoyed in his previous job and about the value of the general training for his firm (see Bishop 1991 for a similar argument). As a result the recruiting firm may place a lower value on a worker with general training than the firm that trained him. The worker will be less likely to quit and will be paid a lower wage. Since the worker cannot fully benefit from his general training in the case of imperfect information, he will not be prepared to bear all the costs of general training. On the other hand, the firm may find it feasible to pay for part, or all, of the costs of the worker's general training. According to Bishop (1991) this argumentation also leads to the conclusion that the lower the informational asymmetries, the higher the wage growth and the quit rate of workers. Informational asymmetries are lower for formal, rather than informal, training, and Bishop (1991) shows in an empirical analysis that formal training has significantly larger effects on wage growth and quit rates than informal training. But Bishop cannot establish a similar result with regard to general training, as compared to specific training. He explains this by noting that informational asymmetries make general training effectively specific as regards wage growth and quit rates.

Thus the empirical research does not reveal strong arguments in favour of the hypothesis of underinvestment in specific or general training. The theory does seem to indicate that the larger the sharing ratio of employees in the costs of either general or specific training, the more likely the probability of under-investment. Bishop (1991) remarks that turnover and under-investment may be high in the U.S., because of job shopping and try-out hiring of young people. Reducing the probability of layoffs, as in Germany, and large internal labour markets, as in Japan, may decrease turnover and under-investment.

\section{Firm size, training and turnover}

Another point with regard to the supply of training by firms concerns the establishment size. Green (1993) mentions several studies which revealed that larger establishments invest more in training than smaller ones. Bishop (1991) also shows that large and medium-sized establishments invest more in training. This may be because large firms have better access to capital markets, can profit from economies of scale when providing training, and are more certain of retaining the employee after the training period due to lower labour turnover and a larger internal market.

Turnover, in particular, is an important issue in recent empirical literature on training. However, turnover is not only a determinant of the probability on training, but is itself dependent on the incidence of training. As mentioned earlier in this subsection, sharing the costs of training reduces the probability of turnover. Moreover, training opportunities for employees may deter them from leaving. A report of the OECD (1993) considers, among other things, enterprise tenure in connection with training. It shows that turnover is lower in larger firms, because of the higher wages and better employment and promotion opportunities in larger firms. Moreover, the OECD analysis shows that "employment stability and training go together" (OECD, 1993, p. 145). However, it is not clear to what extent the causation between

25. Given that completely specific training has, by definition, no value for another firm. 
turnover and training runs both ways.

\subsection{Learning-by-doing}

The concept of learning-by-doing has been widely used by micro-economists, industrial economists and international trade theorists (Malerba, 1992). Also labour economists often refer to learning-by-doing, together with other forms of on-the-job training, to explain productivity increases at the individual level. This subsection will briefly refer to learning-by-doing at the individual level, learning-by-doing at the firm level, and the firm-specificity of learning-by-doing. These various forms of learning-by-doing are summarized in diagram III (see appendix A).

Learning-by-doing at the individual level

The concept of learning-by-doing is often used by labour economists to explain part of the age-earnings or the experience-earnings profile (see subsection 2.1). In this context learning-by-doing, shown in the bottom right-hand part of diagram III, is part of on-the-job training, along with the two forms of investment in training on the right-hand side of diagram II (see subsection 3.1 and appendix A). The experience or age of individuals is often used as a proxy for on-the-job training. Due to lack of training data, Mincer (1974) takes the work experience of individuals as a proxy for investments in training during their work life. Later, when training data became available, he compared the direct method which estimates the relationship between training, the learning contents of jobs and wage profiles with the indirect method which estimates the relationship between work experience as an indirect proxy for training and wage profiles (Mincer, 1989b). He comes to the conclusion that the empirical results of the two methods do not differ very much and that about two thirds of the rise in wage profiles stems from investment in training. The residue is to a large extent a result of job searching. Another illustration of the use of work experience as a proxy of both investment in training and learning-by-doing at the individual level is given by Hashimoto and Raisian (1992). They take the number of years of tenure in the firm as a proxy for firm-specific capital, whereas years of work experience is a proxy for general market experience.

Although we have drawn a clear conceptual distinction between investment in training and learning-bydoing, we also noted that in practice it is not easy to distinguish between informal forms of investment in training, in particular, and employees' learning-by-doing on the other hand. ${ }^{26}$ Both are usually regarded as on-the-job training, and are shown in the bottom right-hand parts of diagram II and diagram III, respectively. However, even the conceptual difference between investment in training and learning-bydoing (explained in subsection 3.1) can be disputed since the fact that learning-by-doing is considered to be a by-product of the production of goods does not imply that learning-by-doing is costless (Rosen, 1972a). For example, Bowman (1974, p. 148) argues that "some jobs have large learning components in them, while other may entail little learning; when people choose between such alternatives they are choosing whether or not to invest in further training" and "the learning opportunity is implicitly sold to the worker, who buys it when he accepts lower wages." Moreover, if competitors discover learning opportunities in the production process, competitive conditions may cause a decrease in product prices. Nevertheless, we have held to the definitions of training and learning-by-doing mentioned earlier.

26. For the time being, we are not considering managers' or owners' learning-by-doing, which is also embodied and internal to the firm, although it is usually not regarded as part of on-the-job training. 
The effect of learning-by-doing in the traditional fashion is illustrated by the well known 'Horndal effect', which is also referred to by Arrow (1962). The Horndal effect describes the average productivity increase of almost $2 \%$ per annum for a period of 15 years in the Horndal iron works in Sweden. During that period the steel plant did not invest in new capital goods, and presumably did not significantly change its production techniques. Therefore it was concluded that the productivity increase can only be understood as the result of the large number of small improvements and modifications that were made, which might be called learning-by-doing or learning-by-experience. The empirical relationship associated with the Horndal effect is known as the 'learning curve'. It describes the relationship between the growth in productivity, although at a diminishing rate, and cumulated output (i.e. the total output from the beginning of production) at the sector or firm level. The progress rate is also connected with the learning curve. A rate of progress of $80 \%$ means that a doubling of the production leads to a decrease in the average costs to $80 \%$ of their original level (for references see Malerba, 1992). Again, average costs decline at a diminishing rate with cumulated output.

The concept of learning-by-doing remains important in recent literature. Bartel and Lichtenberg (1987, see subsection 2.1) make use of the concept when they state that experience with a production technique (proxied by the mean age of the capital stock) shifts the cost function of a firm downwards (or its output function upwards). However, it seems that learning-by-doing is one of the many different processes of learning by firms. Malerba (1992) remarks "that learning processes may be more than simple learning by doing and that the effects of learning may be more than just average cost reductions." He distinguishes learning-by-doing from learning-by-using, to refer respectively to learning related to the production activity or output and learning related to the use of inputs (see Rosen's model, 1972b, below). The traditional learning curve takes only these two learning processes into account, but Malerba distinguishes another form of learning that occurs in the firm, that is learning by searching. This form of learning is related to formalised activities (for example R\&D) intended to generate new knowledge. Other forms of learning distinguished by Malerba are external to the firm and are related to the knowledge needed to absorb new developments in science and technology, knowledge about competitors, suppliers, and users, and knowledge about the opportunities of cooperating with other firms.

\section{Firm-specificity of learning-by-doing}

Individuals can learn about general, i.e. market, activities (see Arrow, 1962) and firm-specific activities (see Rosen, 1972b). The distinction is analogous to that between general and specific training. Arrow assumes that learning is unmarketable because it is available for all (via spillovers), as shown in the top left-hand part of diagram III. Moreover, Arrow takes the cumulative production of capital goods (i.e. cumulative gross investment) instead of the cumulative output as an index of experience. According to Arrow only new vintages of capital goods provide opportunities for learning-by-doing, because once the investment has been made, productive efficiency cannot be altered by subsequent learning-by-doing. This implies that all new knowledge due to learning-by-doing is completely embodied in new vintages of capital goods. Thus contrary to the above Horndal effect, learning-by-doing in Arrow's model takes place only because of the production of capital goods. Improvement in the efficiency of new capital goods is considered as technical change (see also subsection 4.2). As noted, the knowledge with regard to this form of learning-by-doing, i.e. the availability of new capital goods (or technical change), is free to all 
firms.

In contrast, Rosen (1972b) emphasizes that the knowledge from learning is fully vested in the firm. Although the model of Rosen (1972b) could easily include the specific capital embodied in the employees of the firm it emphasizes, like most of the literature with regard to learning-by-doing in those days, the entrepreneurship and knowledge of owners or managers. The knowledge is an asset of the firm, but it may be limited to the working life of the owner or the manager. This is shown in the bottom right-hand part of diagram III, where learning-by-doing that is embodied in the managers or owners is included under individual, firm-internal knowledge. Such knowledge may also be transferable when selling the firm (i.e. disembodied knowledge), independent of the owner or manager, which is shown in the top right-hand part of diagram III. However, in both cases the knowledge is specific to the firm, because it is directly related to the accumulated production costs of the firm. Rosen (1972b) distinguishes two models that make learning a function of either output or inputs. If we make use of the production function in subsection 2.2, then learning can be incorporated as follows.

$$
Y_{t}=f\left(L_{p} Z_{t}\right)
$$

Variable $Z_{t}$ represents the accumulated knowledge from learning-by-doing at the beginning of period $t$. In Rosen's model variable $L_{t}$ represents a composite market input, which in this paper is equivalent to the effective labour input introduced in subsection 2.2. Furthermore, Rosen (1972b) assumes diminishing returns to both factors and complementarity between $L$ and $Z$. His first version makes learning a function of outputs, and it is known as the 'joint product' (referring to learning as a by-product of production $Y$ ):

$$
\Delta Z_{t}=Z_{t+1}-Z_{t}=\beta Y_{t}
$$

where $\beta$ is a constant. The second version asserts that learning is only directly proportional to input (i.e., the effective labour input), as a result of experience relating to the supervision and the direction of inputs:

$$
\Delta Z_{t}=\alpha L_{t}
$$

where $\alpha$ is a constant.

\subsection{Substitution between different forms of human capital}

Now we have considered the different forms of human capital relevant at the firm level, it is interesting to note that the initial daily education of newly recruited workers is costless for firms (disregarding the taxes paid to finance the educational system), whereas firms usually have to share the costs of training (see subsection 3.1). If initial schooling and training are substitutable, firms have the option of recruiting over-educated workers, who would need little or no training, rather than training workers with the usual (required) level of education. This effect would be expected to lead to a lower incidence of training for more highly educated workers. From a social point of view, such over-education of workers ${ }^{27}$ may be less wasteful if it is at least used as a substitute for training in firms. However, complementarity between different forms of human capital also plays a role. For example, it may be more profitable for the firm to hire workers with higher educational qualifications because these have the effect of lowering the cost of

27. For a short introduction and some references on over-education see Groot (1993b). 
the training course which all workers require to achieve expected productivity levels. Less educated workers might be expected to take longer to complete the training or to have a higher failure rate, both of which costs the employer money. This effect would increase the probability of training for more highly educated workers. Thus the degree of substitutability or complementarity between initial education, training and experience is of some importance. Similar considerations apply to the relationship between general and vocational education. These points will be discussed below.

\section{Education, training and experience}

From a human capital point of view, initial education may be complementary to, or substitutable for, training (Mincer 1989b). The complementarity of initial education and training can be explained by the fact that individuals with greater innate abilities and larger opportunities to finance human capital investments will invest more in both initial education and training. Moreover, initial education may increase the rate or quality of learning during training, and may therefore decrease the costs of acquiring human capital by training. Substitutability of initial education and training would arise because a worker with a higher level of initial education needs less training or less learning-by-doing (i.e. experience) to accumulate human capital.

Screening theory provides an alternative explanation for the relation between initial education and training. For example, Spence (1973) states that educational qualifications signal potential productivity. This means that initial education and the probability of training are expected to be positively related. Thurow (1975) also regards educational qualifications as a selection device or signal for employers. Therefore more highly educated individuals get a higher position in the so-called labour queue. Individuals on top of the labour queue are selected first by employers, because they have a higher trainability which reduces the cost of on-the-job training before the worker reaches the productivity maximum. This productivity maximum is determined by the job rather than by the characteristics of the worker. The higher the worker's initial education, the lower the training costs. Thus Thurow (1975) suggests that employers assume the existence of an inverse relationship between a worker's initial education and the amount of on-the-job training he will require to achieve the maximum performance associated with the job. This implies that workers, who know that employers assume the above inverse relationship, may compete for a job by investing in initial education before they offer themselves on the labour market (job competition). Consequently, this mechanism may cause over-schooling of workers.

Empirical research shows that the chance of an individual receiving training is larger the better qualified he is (see for example OECD, 1991 and Green, 1993). Mincer (1989b) notes that all the empirical studies he listed in a short review section of his study confirm that the number of years of initial schooling is positively related to on-the-job training. Bishop (1991) also comes to this conclusion for newly hired employees. It may be that better qualified workers are more likely to benefit from training or have lower costs of training. So these results support the hypothesis of complementarity between education and training. However, other authors point to the relevance of distinguishing the level of education required for a job from the under and over-education of the workers actually in that job. Hersch (1991) points out that training time is significantly negatively related to the over-education of workers, and is not significantly related to years of schooling. According to Hersch (1991) the overeducation of workers may indicate a greater innate ability and may lead to lower job satisfaction, resulting in a higher chance of turnover. This makes it unattractive for either the employer or the employee to invest in specific training. Sicherman (1991) also finds that over-educated workers require 
less training and experience. According to Sicherman (1991) this points to a trade-off between initial schooling and training or experience, which supports the hypothesis that different forms of human capital, such as initial schooling, training and experience, are substitutable. In subsection 2.1 we have already mentioned the empirical study by Bartel and Lichtenberg (1987), which reveals that workers' initial education and experience are substitutes when using a particular production technique.

Groot (1993b), however, finds no evidence for either the complementarity or substitutability of overeducation and training. His empirical research reveals that workers who are correctly allocated to a job, i.e. according to their required level of education, have the highest probability of participating in training, while under-educated workers have the lowest. Furthermore, Groot (1993b, p. 300) mentions the possibility that "in some jobs overeducation is only partially utilized, and in some jobs overeducation is not utilized at all." This may imply that whether over-education is substitutable for or complementary to training is dependent on the occupation the employee works in, which may explain the differing conclusions in the empirical studies above. This is supported by an empirical analysis by Hill (1991). Moreover, education and occupational experience (i.e. human capital acquired by learning-by-doing, that is on-the-job in a previous job, see subsection 3.2) seem to be substitutes with regard to reducing training time and training costs. This implies that some workers have a relative advantage for particular occupations, and the empirical results of Hill (1991) indicate that firms hire those workers who have qualifications that reduce training costs and training time the most.

Thus the empirical research does not lead to clear conclusions with regard to the substitutability of initial education, training and experience. Nevertheless, it tends to suggest that better qualifications acquired by initial education increase the probability of training, although over-education may be substitutable for training. Moreover, experience and initial education seem to be substitutes. However, these conclusions depend on which occupations and which training methods are being analyzed.

\section{Types of education and training}

McMahon, Jung and Boediono (1992) point to the relevance of the complementarity between general education on the one and vocational or technical education (VOTEC) on the other hand. To compute the social rates of return for education in different regions of Indonesia in 1986, they use a nested CES production function that allows VOTEC, general education and physical capital to be complementary with one another but states that all three are substitutable for uneducated labour. They mention some empirical evidence to underpin their capital-skill complementarity hypothesis, which states that both kinds of education are more complementary with physical capital than is uneducated labour (see also subsection 2.2). Assuming these complementarities, they find support for the hypothesis that the cost effectiveness of the educational policy by the government, reflected by the social rates of return, can be improved in some regions by choosing an optimal (or better) mix of VOTEC and general education.

As to the type of training a worker may enjoy, both the occupation of the worker and the required firm specificity of training determine the choice of the training method. The firm can choose between informal internal training, formal internal training or formal external training. These training methods are shown in diagram II in the bottom right-hand part, the top right-hand part and the top left-hand part, respectively. Empirical analysis by Hill (1991) shows that firms prefer formal external and formal internal training in occupations in which schooling is more efficient, and they prefer informal internal training in occupations in which occupational experience is more efficient. Another determinant for the choice of training method 
(Hill, 1991) is whether the firm requires generally or specifically trained workers. If general training is required, firms spend more on formal external and formal internal training methods, and if specific training is required firms spend more on informal internal training methods. Hill (1991) also shows that firms spend more on general training to train workers with higher education and spend more on specific training or a mix of both general and specific training to train workers with lower education (high-school graduates in Hill's study). Once again we see that empirical studies concentrating on different training methods (formal or informal, general or specific), different occupations or different educational categories may come to different conclusions with regard to the substitutability of education and training.

\subsection{Skill obsolescence}

This section briefly discusses the skill obsolescence of workers. The flattening out or diminishing of the age-earnings profile some years before workers' retirement, which is often accounted for by adding a squared age, experience or tenure variable to the earnings function of workers (see for example Mincer, 1974 and Hashimoto and Raisian, 1992), in fact provides an indication that, sooner or later, older workers become less productive.$^{28}$ Firstly we will discuss obsolescence and its causes, and secondly, if and how this could be remedied by the firm. In particular, training of older workers will be mentioned as a remedial factor for obsolescence.

\section{Physical and economic depreciation of human capital}

In an empirical analysis, Gelderblom and De Koning (1992a) present the results of a large-scale survey among over 1600 Dutch firms and institutions. They show that, on average, both the productivity and wages of workers reach their peak between the ages of forty and fifty. In line with the age-earnings profile mentioned above, productivity and wages tend to decline after this age, which is usually seen as an indication for obsolescence. Both the physical and economic depreciation of workers may cause this decline (Van Dalen, 1993, see also De Grip, Groot, Heijke and Willems, 1990). Van Dalen (1993) enumerates some reasons for the physical depreciation of workers. The decrease in the productivity of older workers is determined by work pressure, health, age and gender. The last two factors are only important when large physical efforts are required, as physical strength declines with age and as women are on average less strong then men. With regard to the first two factors, older workers seems to be more sensitive to work pressure (time pressure and working at different tasks at the same time), have a higher chance of occupational disablement and have higher sickness rates (see also Gelderblom and De Koning, 1992a,b). Higher sickness rates were found in particular for workers in production jobs (who more often are involved in work in which physical efforts are required).

Economic depreciation may also be a cause of obsolescence. However, in contrast to physical depreciation, it is not obvious here that age plays an important role. As Van Dalen (1993) stressed, the decline in productivity in the case of economic depreciation is not directly linked to age, but to the obsolescence of human capital. Like physical capital, human capital depreciates due to technical change, that is, the available human capital of workers is unsuited or less suited to new production techniques. Similarly, De Grip (1987) argues that changes in the demand for labour, for whatever reason (thus including technical change, but also a change of consumer preferences), may result into a

28. Therefore we will not pay too much attention to an analysis of obsolescence by means of the age-earnings profile mentioned in subsection 2.1 . 
smaller ex post rate of return for human capital investments than expected ex ante. When this happens during the initial schooling (or training) of individuals, this form of obsolescence is called 'in process' obsolescence of schooling (De Grip, 1987). Moreover, since a change in production techniques alters the firm's demand for specific rather than general skills, firm-specific skills have a higher probability of economic depreciation. Another important cause of economic depreciation is the non-use of knowledge and skills, for example during unemployment.

It follows that obsolescence due to economic depreciation is not a phenomenon to which only older workers are subject. But most empirical research concentrates on obsolescence among workers of fifty years or older. The empirical results indicate that older workers' real wages relative to productivity are too high (see for example Gelderblom and De Koning, 1992a, and for references Van Dalen, 1993). These relatively high wages of older workers cannot be explained by human capital theory, as this theory suggests that due to the sharing of the costs of specific and even general training (see subsection 3.1), the real wage is higher than the marginal productivity at the beginning of someone's working career, and lower than marginal productivity towards the end of someone's working career. However, Gelderblom and De Koning (1992a) refer to what they term 'contract theory' to explain the relative high wage of older workers. ${ }^{29}$ According to Gelderblom and De Koning (1992a) these theories indicate that employers postpone wage increases for workers until they are approaching the end of their working careers. By postponing wage increases of new workers, employers want to reduce the costs of uncertainty as to the productivity of new workers. Employers also want to diminish the turnover of workers in this way and to give them incentives to achieve maximal performance till the end of the contract. However, the consequence may be that when older workers become less productive while still enjoying relatively high wages, employers want to get rid of them. ${ }^{30}$

\section{Remedial policies}

Employers can pursue several policies to prevent the negative consequences of obsolescence such the early retirement or disablement of older workers and the economic depreciation of the human capital of all workers (see Van Dalen, 1993, and Gelderblom and De Koning, 1992a). Employers can offer real wages to older workers which better reflect their marginal productivities (i.e., lower wages). Another option is to replace older workers by younger workers or physical capital. Some support for the viability of this option may be found in the empirical study of Hebbink (1992). He shows that older workers are substitutable by physical capital and medium-aged workers in the Netherlands. On the other hand, it is also possible to let workers stay with the firm by offering them another job or by increasing their productivity by training. The first option is mentioned by Gelderblom and De Koning (1992b) and Van Dalen (1993), who state that firms should profit more from some advantageous characteristics ${ }^{31}$ of older workers such as superior problem solving, negotiating and public relations skills, consistent performance, lower accident rates, etc. These may more than compensate for the decline in productivity due to other characteristics. Moreover, Hebbink (1992) shows that older workers are complementary with young workers, which suggests that there may be an optimal mix of older and young workers in a

29. By contract theory they mean various theories such as the implicit contract theory and the theory of efficient wages (for references see Gelderblom and De Koning, 1992a, p. 27).

30. Gelderblom and De Koning (1992a) offer this as an important reason why Dutch workers over the age of 50 have a high probability of being discharged under the Disablement Act, which is financed by social insurance premiums and is attractive for both employers and employees.

31. See also the concept of comparative advantage mentioned in subsection 2.1. 
firm. So firms can profit from older workers by applying a human resource policy better suited to older workers, for example offering them other jobs, possibly in connection with lower wages.

The second option may also help in dealing with the economic depreciation of all workers (due to technical change or change in the product demand). Subsection 3.1 mentioned several studies that revealed empirical evidence for the hypothesis that training increases the productivity of workers. Some studies also showed that training increases productivity more than wages (i.e. benefit sharing). These findings are confirmed by Gelderblom and De Koning (1992a) ${ }^{32}$ For other references see Van Dalen (1993), who also finds no significant differences between older and other workers with regard to the productivity-increasing effect of training. ${ }^{33}$ Gelderblom and De Koning (1992a, 1993) remark that these results are in line with other research which reveals that older worker do not have a smaller learning capacity than younger workers, so long as the didactics of the training method are suited to older workers. Moreover, Gelderblom and De Koning (1992a, 1993) note that the obsolescence of older workers as indicated by their falling productivity is reinforced because they participate less in training courses than younger workers. The hypothesis that older workers participate less in training courses is confirmed by an empirical study of De Grip et al. (1990). Thus, greater participation of older workers in training courses is recommended if employers want to increase the workers' productivity.

However, the fact that older workers participate less in training follows directly from human capital theory. As De Grip (1987) argues, older workers have higher opportunity costs when participating in training (because they earn higher wages, see subsection 3.1 ) and have a shorter pay-back period. Both circumstances mean that it is not attractive for either the worker or the employer to invest in the human capital of older workers. According to Van Dalen (1993) the relatively short pay-back period of older workers can be lengthened if employers and employees agree on postponing retirement. In this context it is interesting that Bartel and Sicherman (1990) find that older workers retire later in industries with higher rates of technical change and on-the-job training. ${ }^{34}$ They explain this by the higher depreciation rates of human capital in industries with high rates of technical change, so that workers have flatter earnings profiles in these industries. As a result older workers have to retire later to capture the returns on investment in human capital. However, if there is an unexpected increase in the rate of technical change, older workers will be likely to retire earlier. In this case it is not attractive for older workers to invest in the required on-the-job training, because they are faced with unexpectedly high depreciation rates while their pay-back period is relatively short. Furthermore, retraining for another job is also less attractive for older workers, because they have accumulated a larger stock of human capital during their working career, some of which will be unusable in another job, and unused knowledge and skills can be lost (De Grip, 1987).

\section{Technical and technological change and the demand for human capital}

This section attempts to give an overview of the relationship between technological and technical change, on the one hand, and human capital on the other hand. Because technological and technical change are usually not properly distinguished, subsection 4.1 starts with defining both concepts.

32. However, they do not include the costs of training in their empirical analysis.

33. Moreover, they find that external courses have a larger impact on productivity than internal courses.

34. The link between technical change and forms of human capital will be discussed in subsection 4.3 . 
Subsections 4.2 and 4.3 discuss the relevance of human capital when a firm experiences technological or technical change. According to Mincer (1989a) human capital plays a dual role in the process of economic growth. First, human capital is a stock of skills used as a factor of production. It can be combined with physical capital and unskilled labour to produce total output. This role has been treated as such in sections 2 and 3 . Second, human capital is a stock of knowledge and thereby a source of innovation and technological change, which makes it a basic cause of economic growth. Subsection 4.2. describes the role of human capital and knowledge in technological change and innovation. Finally, subsection 4.3 considers the impact of technical change on the demand for human capital. Because technical change alters production techniques and factor intensities, the complementarity and substitutability of human capital with other production factors play a significant role.

\subsection{Technical and technological change}

Both the terms 'technological' and 'technical' change are used to indicate that some progress has been made with regard to the production of goods. It is not easy to make a clear distinction between them, and they are often used interchangeably. Nevertheless, Freeman discusses the conceptual difference between technical and technological change as follows: "For the economist the rate of technological change is conceptually distinct from the rate of technical change. The latter is usually defined statistically as the 'residual' factor explaining that part of measured growth which cannot be attributed to increases in the inputs of labour and capital. Almost any significant slow-down in economic growth therefore implies a deceleration of the rate of technical change so defined. But the underlying rate of technological change may be unaffected, since this refers to changes in the body of knowledge relating to techniques of production." (citation from Pattel and Soete, 1988, p. 123)

Nelson and Phelps (1966) implicitly make a similar conceptual distinction between technical and technological change when discussing technological diffusion (see subsection 4.2). They relate technical change to the level of technology in practice, that is the production techniques which are actually in use. They relate technological change to the theoretical level of technology, that is the level of technological knowledge. This distinction fits very well with the analysis of the production process in neo-classical theory, as discussed by Verspagen (1992). According to Verspagen (1992) neo-classical theory refers to the techniques used to indicate technical change and to the state of technological knowledge to indicate technological change. A technique is defined as a combination of production factors, such as labour, human capital and physical capital. A production function relates the (infinitely) large number of techniques to the resulting outputs. Given the form of the production function (for example CES, CobbDouglas or Leontief), the general state of technological knowledge and the relative factor prices, the technique chosen is the one that maximizes profits (or minimizes costs). This results in either a labour intensive, a physical capital intensive or a human capital intensive production technique. Changing either the general state of technological knowledge or the relative factor prices may lead to another choice of production technique, that is it may cause substitution of production factors. The possibilities for substitution are dependent on the form of the production function. In a Leontief production function the input ratios (for example the capital-labour ratio) are fixed, whereas in a Cobb-Douglas production function the elasticity of substitution equals one.

Moreover, Verspagen (1992) notes that in neo-classical theory the increase in the general state of technological knowledge (or technological progress) is assumed to increase the productivity of every technique without changing the total set of techniques available. As noted, this may induce the 
substitution of production factors. However, the productivity of all techniques may be altered to the same extent, in which case technological change is said to be Hicks neutral (i.e. capital intensity remains unchanged), or it may be altered in different proportions for the various techniques, in which case technological change may be either labour-saving or capital-saving. However, as Freeman and Soete (1987) argue, the neo-classical way of representing technological change has some important drawbacks. We will not go into details, but will note one important drawback. The neo-classical production function allows for factor substitution on the assumption of an infinite number of possible combinations of production factors to produce a given output. Besides, it emphasizes the relevance of the increase in the productivities of production factors and the substitution of labour for capital due to technological change. Therefore technological change is regarded only in terms of cost reductions, and as a result neo-classical theory stresses the importance of process innovations and the price elasticities of demand. On the other hand, Freeman and Soete (1987) point to the importance of the income elasticities of demand in relation to new and improved products. Moreover, Soete (1987) remarks that the macro-economic impact of technological change is both input-saving and demand-creating. These two effects work in opposite directions with regard to the level of employment. The effects of technological change at the firm and sector level on employment and in particular on the demand for skills will be discussed in subsection 4.3 .

\subsection{Technological knowledge, R\&D and diffusion}

The citation of Freeman at the beginning of subsection 4.1 pointed to the important role of knowledge in technological change. This raises the questions of whether and why knowledge is different from or equal to human capital, and how it can be generated. These questions will be discussed in the first and second parts of this subsection. This analysis also highlights the role of human capital in technological change. Moreover, as R\&D is an important determinant of technological change, the relevance of human capital for research and development will be briefly discussed. Finally, the role of human capital for technological diffusion will be analyzed.

\section{Knowledge and human capital}

Because some references in the literature of the recently developed endogenous growth theory explicitly discuss the concepts of knowledge and human capital, we will make use of those references. Endogenous growth theory builds on the neo-classical theory of, for example, Solow (1957) and Arrow (1962), and is therefore also known as new neo-classical growth theory. Although the insights of endogenous growth theory have many different consequences, for example for the growth paths of economies and for government and trade policies (see Grossman and Helpman, 1992, Van Ewijk, 1993), we will only briefly consider what endogenous growth is, and what role knowledge and human capital play in endogenous growth theory.

With regard to the first question, endogenous growth theory tries to explain the economic growth of countries by assuming increasing returns to scale in the aggregate production function. In old neoclassical models the production function usually exhibits constant returns to scale, in other words degree one homogeneity. This implies that, if a firm multiplies the factor inputs by some amount, the firm output is multiplied by the same amount. The same holds for the aggregate production function. However, due to the existence of externalities between firms in endogenous growth models, other firms may profit from the increase of factor inputs of one single firm. So externalities result in a more than proportional 
increase in aggregate output with factor inputs, that is, increasing returns to scale. An important aspect of endogenous growth theory is that it focuses on modelling externalities by knowledge spillovers (see below) from investments in technological knowledge (such as research and development) or human capital. The output of these investments, for example innovations or human capital skills, is an input in the production function of all firms.

The relevance of the second question is that knowledge, in particular knowledge generated by R\&D (i.e. technological knowledge), is often regarded as a principal source of economic growth. This can be explained by two features of knowledge (see Romer, 1990). First, knowledge is a nonrival good or input factor. One example of knowledge is a blueprint (design) of a new good, which can be used as often as desired once the blueprint is created. Input factors such as labour, physical capital and human capital are usually assumed to be rival, because their use by a firm precludes any other firm from using it during the same period. Other examples of nonrival goods or inputs (from Romer, 1990) are a scientific law, a principle of mechanical, electrical, or chemical engineering, a mathematical result, software, a patent, a mechanical drawing, etc. The second feature of knowledge is that, because it is a nonrival good, competing firms cannot or can only partially be excluded from using knowledge spillovers. As mentioned earlier, knowledge spillovers are externalities that cause increasing returns to scale in aggregate production functions. For example, with constant returns to scale, a doubling of output can be achieved by doubling of rival inputs alone, which implies that simultaneously increasing the state of knowledge results in increasing returns to scale. These two features of knowledge, i.e. unbounded growth and incomplete appropriability, are generally recognized to be relevant for self-sustaining growth in endogenous growth theory.

Moreover, according to Romer (1990), human capital is embodied knowledge, tied to a specific worker. This makes it different from disembodied knowledge such as technological knowledge or the above mentioned examples, in that each worker can acquire only a limited amount of skills during his working life. Moreover, those skills are lost if the worker dies, whereas disembodied knowledge outlives individuals. Although Romer (1990) argues that knowledge is different from human capital, Lucas (1988) assumes that embodied knowledge can outlive individuals if human capital is passed on to younger generations (see below). According to Lucas (1988) the stock of (technological) knowledge in a country is undisputably related to human beings, because (p. 19) "human capital accumulation is a social activity, involving groups of people in a way that has no counterpart in the accumulation of physical capital." In general, however, knowledge is distinguished from human capital by regarding the nonrival and partially nonexludable features of knowledge, whereas human capital is embodied in human beings and therefore rival and excludable.

\section{Generation of knowledge}

We have argued that knowledge can be distinguished from human capital by using the criteria of nonrivalry and nonexludability. Nevertheless, Lucas (1988) pointed to the relevance of human beings in the accumulation of knowledge by stating that all knowledge is embodied. ${ }^{35}$ As this paper deals with distinguishing several kinds of human capital, we find it useful to consider two ways in which knowledge

35. Moreover, empirical research on endogenous growth theory by, for example, Den Butter and Wollmer (1993) treats the stock of 'technology capital' (the aggregate of a country's R\&D output and imported technology) as an important part of both the stock of human capital and the stock of physical capital in a country. This illustrates the somewhat confusing linkages between technology and other factors of production. 
can be generated according to endogenous growth theory (see Grossman and Helpman, 1992, and Verspagen, 1992). Moreover, this will reveal that the generation of knowledge and technological change are strongly interrelated. Knowledge is acquired, firstly, as a by-product of investing in physical or human capital and, secondly, in a distinct research sector from the activities of basic researchers, i.e. research and development. Both will be discussed below. ${ }^{36}$

The first type of knowledge acquisition was already mentioned in subsection 3.2, where it was said that Arrow (1962) treats learning-by-doing is a by-product of the cumulative investments of all firms in the economy. However, subsection 3.2 also mentioned that learning-by-doing arising as a function of cumulative output, investment or time is just one way in which firms can learn. Learning within a firm (internal learning) is generated from several activities such as production, design, engineering, organisation, marketing and R\&D (Malerba, 1992). Moreover, the knowledge due to learning of one firm may be freely available for all firms (i.e. knowledge spillovers due to external learning), which implies that knowledge is assumed to be partly or completely nonexcludable. So firms may have different levels and types of 'knowledge capital' accumulated through time. A firm's specific stock of knowledge may generate incremental innovations which consist of modifications and improvements to existing products or processes. This is called incremental technical change (Malerba, 1992). The increase in the stock of knowledge due to internal and external learning is called technological change (since learning refers to improving the state of knowledge). This form of technological change is an accidental consequence of a firm's private investment decisions.

In endogenous growth theory we also find that investments by firms have external effects in the form of knowledge spillovers. In for example Romer (1986), firms invest in knowledge which can only partially be kept secret. Therefore both the state of knowledge in a firm and the aggregate level of knowledge (of a sector or the entire economy) are arguments in the production function. Lucas (1988) assumes that the general stock of knowledge accumulates due to external effects which arise from both investments in training and learning-by-doing of individual workers. Here knowledge acquired, whether by investments in initial education or by learning-by-doing, is called human capital. Again, externalities ensure that new knowledge can be used by all firms. According to Romer (1986) and Lucas (1988) the production function of an individual entrepreneur can be described as follows (see Verspagen, 1992):

$$
Y=f\left(N, H, K, H^{*}\right)
$$

Here the firm production $Y$ is dependent on conventional inputs such as unskilled labour $N$ and physical capital $K$ (both of which are subject to diminishing returns, as in subsection 2.2.), and two inputs of knowledge. $H$ represents the stock of a firm's own investments in knowledge or human capital, which are also subject to decreasing marginal returns. $H^{*}$ shows the level of public knowledge, which in Romer (1986) equals the stock of aggregate firm investments (of the entire economy) in knowledge and which accounts for the increasing returns to scale of the production function. On the other hand, in Lucas (1988) the level of public knowledge $H^{*}$ is indicated by the average level of human capital of all individuals in an economy. The level of public knowledge represents the above mentioned externalities or knowledge spillovers. Moreover, Romer (1986) argues that including the stock of public knowledge in the production function of a firm results in increasing returns in the production from all input factors, i.e. labour, capital and total knowledge (private knowledge, i.e. of an individual firm, plus public knowledge).

36. See Young (1993) for a model that emphasizes the interdependence between research activity in the laboratory and production experience on the factory floor. 
For an economy as a whole, this may account for self-sustaining growth, which is an essential feature of endogenous growth models. However, Lucas (1988) shows that human capital may be an important factor for the establishment of self-sustaining growth in an economy. He assumes that both the average human capital of the population and the proportion of human capital used for schooling or learning activities may determine the rate of self-sustaining growth. The assumption that investments in schooling or learning-by-doing are proportional to the existing average level of human capital follows from Lucas' idea that part of human capital of a population is passed on to younger generations.

The second type of knowledge acquisition comes about by formal research conducted in a laboratory setting, in other words by R\&D activities. In exogenous growth theory, R\&D activities take place in a research sector separated from the rest of the economy and financed by taxes collected from the government (see for example Shell, 1967). This results in an exogenously determined rate of technological change, although it may be dependent on the willingness of the government to impose taxes in order to provide funding for research. However, Grossman and Helpman (1992, subsection 2.4) present an example of a simple endogenous growth model in which economic growth is no longer exogenous but self-sustaining, though the government still finances basic research from tax revenues. They assume that researchers from the research sector make their findings (i.e. their output) immediately available for all sectors in the economy so that these findings (externalities or knowledge spillovers) are inputs for all sectors. As a result the level of productivity of an economy increases with the cumulative output of the research sector. Moreover, they assume that the level of productivity of the research sector equals the productivity of other sectors. ${ }^{37}$ Self-sustaining growth is established because the output of the research sector, i.e. knowledge, can be used as an input factor for all sectors of the economy, including the research sector.

Moreover, Verspagen (1992) emphasizes the difference between specific and general knowledge generated by the research sector. Specific knowledge is represented by blueprints, which provide guidelines for the producers and enable them to produce consumer or intermediate goods at lower cost or higher quality. Specific (technological) knowledge can be appropriated, for example through patents. General knowledge refers to the existence of externalities or knowledge spillovers. General (technological) knowledge cannot be appropriated and therefore can be used by other producers. New innovations (blueprints) build upon the previous one by improving the existing production process (process innovations). Hence productivity is increased, which is called technological change. This is accompanied by positive (intertemporal) externalities in the innovation process, since the blueprint of the innovating firm in the present period will be sold to other firms in future periods. Negative (intertemporal) externalities may occur if a new innovation makes the previous one (possibly of another firm) obsolete. Moreover, Romer (1990) assumes that general knowledge cannot be used directly for the production of goods, although it raises the productivity of all firms in the research sector. Thus, the use of general knowledge is not confined to the firm by which it has been developed (non-appropriability).

In Romer (1990) the generation of general knowledge is explicitely modelled as a by-product (an externality) of the production process in the research sector. This production process is in fact focused on the generation of new blueprints (product innovations or designs, which embody the specific knowledge). Romer (1990) measures the output of the research sector by the number of new blueprints,

37. The conclusions of the simple model of Grossman and Helpman (1992) do not change much if it is instead assumed that the productivity growth of the economic sectors is proportional to the productivity growth of the research sector. 
which is also a measure of the knowledge needed for the production of more new designs. Besides knowledge and a productivity parameter, human capital is an important input factor for the production of new designs in Romer's model. Also Grossman and Helpman (1992) underline the importance of human capital for the research sector by assuming "in accordance with reality, that specialized skills are employed relatively more intensively in the industrial research lab than elsewhere in the economy." Moreover, they state that skilled workers are hardly substitutable for unskilled workers (both in the research lab and in the firm).

Thus in endogenous growth models knowledge may be generated with (Grossman and Helpman, 1992 and Romer, 1990) or without (Romer, 1986, and Lucas, 1988) distinguishing a separate research sector. Although the generation of knowledge may be accounted for by firms (Romer, 1986 and 1990, Grossman and Helpman, 1992), individuals may also generate knowledge (Lucas, 1988). However, the role of human capital in the generation of knowledge or knowledge spillovers is only explicitely modelled in Romer (1990) and Lucas (1988). The former considers human capital as an important input factor for the generation of knowledge in the research sector. The latter considers spillovers from individual investments in human capital to public knowledge.

\section{Research and development}

Since human capital is an important input factor for investments in R\&D, human capital contributes to productivity growth that results from advances in technological knowledge. However, it should be realized that R\&D is involved in a complex innovation process. The first stage of this process is the invention, i.e. ideas or insights of new technical opportunities. Parker $(1978$, p. 50$)$ describes the innovation process and the resulting diffusion as follows: "The innovative process can be divided into four functions: invention, entrepreneurship, investment and development. The entrepreneurial function involves deciding to go forward with the effort, organising it and obtaining financial support. Investment is the act of risking funds for the venture. Development is the lengthy sequence of detail-orientated technical activities, including trial and error testing, through which the original concept is modified and perfected until it is ready for commercial utilisation. Innovation thus covers all the activities in bringing a new product or process to the market. It is the pre-imitation stage. The term 'diffusion' is reserved to describe what occurs later, and includes the spread of an innovation and its adoption by rivals." Innovation diffusion will be discussed at the end of this subsection.

A survey of econometric studies by Mairesse and Sassenou (1991) shows the importance of R\&D for productivity growth at the firm level. According to Pattel and Soete (1988) the advantage of using R\&D expenditures as a proxy for the input of technological knowledge is that R\&D expenditures are an input proxy like conventional inputs such as labour and capital. However, both Pattel and Soete (1988) and Mairesse and Sassenou (1991) point to some difficulties with regard to the empirical research on the relation between $R \& D$ and productivity growth. It is not only difficult to measure productivity, but also to decide whether particular investments belong to R\&D. Moreover, a proxy such as R\&D expenditures corresponds only to an investment flow, whereas a stock flow of previous and present R\&D expenditures would be preferable. Nevertheless, this raises the difficulty that information is needed about the time lags between R\&D expenditures and their effect on productivity. These time lags relate to the complexity of the innovation process described above, in particular the length of the period of the R\&D project, and the uncertainty and delay in the revenues of the project. Moreover, the rate of depreciation of R\&D capital has to be estimated in order to construct an R\&D stock measure. Finally and very 
crucially, it is difficult to distinguish and measure the effects of a firm's R\&D investments on its output, on the one hand, and productivity growth due to knowledge spillovers of investments in R\&D by other firms on the other hand. ${ }^{38}$ Spillovers occur not only between firms or sectors, but also between public and private research. The relevance of research at universities for corporate R\&D expenditures and corporate patents has been shown by an empirical study of Jaffe (1989). Here we have to realize that expenditures on research in universities may coincide with public expenditures on higher education. This once more illustrates the relevance of human capital for R\&D.

\section{Technological diffusion}

Human capital is not only relevant for the production of technological knowledge, but also for the rate of technological diffusion. This is illustrated by Nelson and Phelps (1966) who suppose that the level of educational attainment of workers is an important variable for the rate of technological diffusion (see also subsection 2.1). What Nelson and Phelps (1966) actually mean by technological diffusion is the introduction of new production techniques. Technological change, i.e. the increase in technological knowledge and process and product innovations, makes it possible to choose a new, more efficient production technique. The change in production techniques in itself is known as technical change and leads to an increase in the productivity of the conventional production factors capital and labour. Nelson and Phelps (1966, p. 70) suggest that "production management is a function requiring adaptation to change and that the more educated a manager is, the quicker will he be to introduce new techniques of production."

They formalize this as follows.

$$
Y(t)=f(A(t) L(t), K(t))
$$

This equation shows the firm production function with output $Y(t)$, capital $K(t)$, labour $L(t)$ at time $t$. Moreover, $A(t)$ represents the level of technological knowledge that is actually used in the production technique. Diffusion of technological knowledge may change the choice of the production technique. In subsection 4.1 this change is defined as technical change. Technical change is here assumed to be Harrod neutral (labour-augmenting), which implies that the same output can be produced with less labour for a given capital stock (process innovation).

Equation (4.3) introduces the theoretical level of technological knowledge $T(t)$, which advances exogenously (contrary to the analysis in this subsection above) at a constant exponential rate.

$$
T(t)=T_{0} e^{\lambda t} ; \lambda>0
$$

If technological diffusion is completely instantaneous, the level of technological knowledge $T(t)$ that is theoretically available for the firm equals the level of technological knowledge $A(t)$ used in the production technique. Equation (4.4) shows that the time lag I between the former and the latter depends on some index of average educational attainment $H$ of the workers in a firm, with $I$ a decreasing function of $H$. This is the basic equation for the first model of Nelson and Phelps (1966).

38. Moreover, Cohen and Levinthal (1989) refer to the 'two faces' of investments in R\&D to clarify that the firm's stock of technological knowledge is not only directly increased by its own R\&D, but also that the firm's own R\&D makes it easier to utilize spillovers from knowledge generated by external R\&D. 


$$
A(t)=\pi(t-I(H)) ; \frac{\partial /(H)}{\partial H}<0
$$

Substitution of (4.3) and (4.4) in (4.2) yields

$$
Y(t)=f\left(T_{0} e^{\lambda(t-l(t))} L(t), K(t)\right)
$$

Differentiating the production function to average educational attainment of workers, we find equation (4.6). This equation is also the result reached by Nelson and Phelps (1966), showing that the marginal productivity of education is dependent on the rate at which the theoretical level of technological knowledge advances, i.e. $\lambda$.

$$
\begin{aligned}
\frac{\partial Y(t)}{\partial H} & =\frac{\partial Y(t)}{\partial(A(t) L(t))} \frac{\partial(A(t) L(t))}{\partial H} \\
& =-\frac{\partial Y(t)}{\partial(A(t) L(t))} L(t) T_{0} e^{\lambda(t-I(H))} \lambda I^{\prime}(H) \\
& =-\lambda I^{\prime}(H) \frac{\partial Y(t)}{\partial(A(t) L(t))} A(t) L(t)
\end{aligned}
$$

The following equation represents a second model of Nelson and Phelps (1966) which is, according to themselves, more realistic than the first one.

$$
\frac{\partial A(t)}{\partial t}=\phi(H)[T(t)-A(t)] ; \phi(0)=0, \frac{\partial \phi(H)}{\partial H}>0
$$

Here the speed of technological diffusion depends on both the level of educational attainment and the gap between the theoretical level of technology and the used level of technological knowledge. Nelson and Phelps (1966) show that in this model the elasticity of the long-run equilibrium level of technology in practice with respect to human capital is increasing with the rate of technological progress $\lambda$.

$$
\frac{\partial A *(t)}{\partial H} \frac{H}{A^{*}(t)}=\frac{H \phi^{\prime}(H)}{\phi(H)} \frac{\lambda}{\phi(H)+\lambda}
$$

where $A^{*}(t)$ represents the long-run equilibrium level of technology in practice. This indicates that marginal productivity of educational attainment is greater, the more technologically progressive the economy is.

This conclusion follows from the assumption of Nelson and Phelps (1966) that education is an important source of technological diffusion. Some recent empirically-oriented research (see for example De Grip and Nusselder, 1989, and Van Dam and Ramaekers, 1992) also makes this assumption. These studies develop technology indicators with regard to the level and type of education and training of schoolleavers and other members of the potential labour force in the Netherlands in order to measure the potential of the labour force for technological diffusion and investments in R\&D. Also Soete and Verspagen (1993) regard the level of educational attainment of the labour force as the breeding ground for technological diffusion.

\subsection{Technology-skill complementarities}

There may be several reasons why investments in technological knowledge leads to a higher demand 
for skills or human capital. ${ }^{39}$ First, in the last subsection it was argued that the R\&D intensive firms or sectors may be relatively more human capital intensive. This implies that human capital may not only be complementary to physical capital (see subsection 2.2), but also to R\&D. Both complementarities are relevant in assessing the consequences of technological change for the demand for human capital. Second, the marginal productivity of highly educated workers turns out to be greater in more technologically progressive firms (see also subsections 2.1 and 4.2). This obviously increases the demand for highly educated workers.

To analyse the effects of changes in technology on the demand for human capital, Mincer (1989c) noticed that an increased supply of educated labour, which has been apparent in most countries during recent decades (see for example Barro and Lee, 1993), reduces its marginal product and therefore the educational wage differential, assuming that no other changes occur. Subsection 2.3 analysed the consequences of an increase in the supply of educated labour, for example of engineers. It found that due to a shift of the labour supply curve to the right, employment tends to increase, whereas both the marginal productivity and the real wage tend to diminish. ${ }^{40}$ However Mincer (1989c) poses the question of why the massive increases in the supplies of educated workers did not lead to a significant downward long-term trend in the profitability of educated workers. He points to the production side of the economy to answer this question. ${ }^{41}$ Given the capital-skill complementarity, one of the (widely accepted) explanations for the increased demand for educated workers is the growth of physical capital and the increased capital intensity in the industrial countries during the last decades. We have to be aware that the change in capital intensity is defined as technical change in subsection 4.1 , since a change in the input ratio indicates that another production technique is being used. Moreover, Mincer (1989c) explains the larger demand for educated workers as a result of technological change. This is confirmed by empirical studies, for example those by Welch (1970) and Bartel and Lichtenberg (1987), which have been discussed in subsection 2.1. These studies found that relatively more educated workers are employed in industries with newer capital vintages or higher R\&D expenditures. The real wages of more educated workers are also higher in those industries. Most empirical studies on this topic use a crosssectional approach, whereas Mincer (1989c) confirms the skill bias of new technologies in a time series approach.

Berman, Bound and Griliches (1993) also found that labour-saving technological change accounted for an important share of the shift in employment from production workers to non-production workers in U.S. manufacturing between 1979 and 1989. Less than one third of this shift is accounted for by a buildup of the defense industry and increased international trade (inter-industry shift). These factors result in a decrease in product demand from those industries with high shares of production workers. However, Berman et al. (1993) found that most of the shifts in employment occurred within four-digit manufacturing industries. These intra-industry shifts were largely unrelated to defense procurements or imports. In Berman et al. (1993), the distinction between production and non-production workers is the only measure of skill. In accordance with the hypothesis that technological progress is skill biased, Berman

39. However, we will not discuss the consequences of technological change for employment and productivity in general here (on this topic see, for example, Reijnen and Kleinknecht, 1992).

40. Of course, this in part depends on the slopes of the demand and the supply curve.

41. This explanation had already been given, for example by Tinbergen (1975), who mentions the race between technological development and education to indicate whether or not the relative income of highly educated people, at a country level, increases over time. 
et al. (1993) find that skill upgrading is positively related to investments in computers and computerrelated technology as well as to $R \& D$ expenditures.

Similarly, Groot and De Grip (1991) find in a cross-section analysis of 100 local Dutch banks that investments in computer equipment and the availability of desk terminals have had a significant positive impact on both the skill level and the share of vocationally skilled workers. Both training policies and recruitment policies are used to upgrade the skills of the banking employees. On the other hand, De Grip, Groot, Heijke and Willems (1990) find no evidence for the impact of technical change on the participation of individuals in training programmes, although they point out that the variable indicating technical change should be improved. Furthermore, an empirical study by Bartel (1991a) confirms that both higher ratios of R\&D expenditures to sales and of capital expenditures to the number of employees increase the probability of the presence of a formal training programme in a firm. Finally, we want to mention the empirical study by Howell and Wolff (1992) who draw attention to the diverse skills needed to perform a job. They reject the adequacy of years of schooling as a measure for workplace skills and replace it by three measures of job-based skill requirements. They show that growth of capital intensity and technical change are only positively related to particular skills.

\section{Conclusions}

The aim of this paper was to give a survey of the literature on the various forms of human capital relevant at the firm level, as a first step towards the development of human capital indicators for the international competitiveness of economic sectors. The paper first considered initial schooling, training and learning-by-doing, all from the perspective of the firm. The substitutability and complementarity between these human capital forms and the obsolescence of human capital were also briefly discussed. Finally, the relationship between technical and technological change and human capital was dealt with. In section 1 the relationships between different forms of human capital, the production function and technological change were introduced by means of diagram I. In this section we will summarize sections 2,3 and 4 and draw some final conclusions.

Subsection 2.1 tried to answer the questions of why investment in initial schooling may increase labour productivity, how human capital input can be modelled in a production function and what impact human capital has on labour demand at the firm level. Human capital theory, screening theory, signalling theory and theories related to research and development and technological diffusion were used to distinguish five possible effects of initial education on labour productivity. First, the 'worker effect' refers to the fact that a worker with more years of initial schooling has a higher marginal productivity in physical terms with regard to the production of a particular good. Second, the 'allocative effect' refers to the greater efficiency of better educated workers in allocating all input factors to the production process (including education itself) between the alternative uses. In fact, education seems to provide the skills to make better decisions based upon the available information. Third, the 'signalling effect' of education refers to the fact that the productivity of workers in a firm may increase because of a more efficient match between the abilities of workers and the job requirements. The educational system selects students with particular abilities and gives them educational credentials. These credentials may be used as a signal or screening device for employers to match the available jobs and workers. Fourth, the 'technological diffusion effect' refers to the fact that better educated workers are more able to adapt to technological change and will introduce new production techniques more quickly. The faster technological change is, 
the higher the marginal productivity of better educated workers relative to less educated workers. Fifth, the 'research effect' refers to the fact that higher education is an important input factor in research and development activities, which in turn is a key factor for productivity growth. Authors mentioning these effects usually analyze the impact of initial education on labour productivity, but we believe that these effects can also be applied to some extent to other forms of investment in human capital, such as training and learning-by-doing.

These five effects may be assumed to be implicitly modelled in the production function of the firm by measuring the effective labour input rather than the conventional labour input measure. The effective labour input corrects for differences in human capital, and can be measured by combining the labour input of different educational categories by means of a function with fixed marginal productivities or by means of a Cobb-Douglas function (see subsection 2.2). Another way to measure the effective labour input is to multiply the number of workers and their human capital. The amount of human capital per worker is measured by the difference between the real wage per worker and the real wage of the least productive worker. In all these methods of measuring the effective labour input, the real wage is assumed to be a proxy for the marginal productivity. Moreover, we have to be aware of the difficulty that measuring human capital by using a separate indicator for effective labour input does not take account the empirically established fact that highly educated workers are more complementary with physical capital than are other workers, i.e. it overlooks capital-skill complementarity. These complementarity differences mean that increasing the input of the production factor physical capital alters the relative marginal productivities of the various labour categories in favour of highly educated labour. However, we have assumed that the stock of physical capital is fixed, in order to analyze the impact of an increase in human capital on both the productivity and the demand for labour at the firm level. In subsection 2.3 we showed that an increase in the supply of engineers, for example, tends to decrease their real wage (which equals marginal productivity) and consequently to increase the demand in that labour segment. Moreover, an increase in human capital per engineer tends to increase both the real wage and the demand for engineers, given a Cobb-Douglas production function with a fixed stock of physical capital.

In contrast to section 2, in which the accumulation of human capital takes place outside the firm through the initial education of potential workers, section 3 discussed the change in the stock of workers' human capital when they are in the firm, viz. by investment in training, learning-by-doing and skill obsolescence. Moreover, the firm can to a large extent decide whether and how to train its workers, whereas the level and type of initial education of the potential workforce is exogenously determined. The firm can only select the level and type of human capital from the total national stock by its recruitment policy. Subsection 3.1 discussed various kinds of formal and informal training organized by the firm itself or by external training institutions. These kinds of training have been summarized in diagram II. Training within the firm is often referred to as on-the-job training and can be formal or informal, and general or specific. According to Becker (1975), completely general training increases the marginal productivity of workers by the same extent in all firms, while completely specific training increases the marginal productivity of employees only if they remain working that firm, and has no effect on the employees' potential marginal productivities in other firms. Empirical research reveals that training, whether it is general or specific, increases the productivity level of workers in a firm.

Moreover, economic theory predicts that the costs (and benefits) of general training are completely borne (received) by the workers, because the marginal productivity increases in equal proportions in all firms when workers receive general training. Due to differences in the increase in marginal productivity 
between firms when workers receive more specific training, the costs (and benefits) of more specific training are shared by the firm and the workers. This sharing of the costs and benefits associated with specific training implies that workers who received firm-specific training are paid above their marginal productivity level during the training period and below their marginal productivity in the post-training period, whereas workers who receive only general training are always paid according to their marginal productivity level. Therefore workers with relatively more specific training have both a flatter ageearnings profile and a lower turnover rate than workers with relatively more general training. Moreover, as workers have to pay for general training themselves, under-investment in general training may occur because the future returns of training are uncertain, workers are less liquid and more risk averse than firms, and capital markets are not perfect. However, empirical research on general training shows that firms share in the costs and benefits of both specific and general training. There is also no strong evidence for the hypothesis of under-investment in general training. This may be due to the existence of informational asymmetries with regard to the value of general training for different firms. Nevertheless, the greater difficulties facing individuals (as compared to firms) in financing human capital investments seem to indicate that the larger the sharing ratio of employees, the greater the probability of underinvestment in training. Other factors that determine the probability of training are firm size and labour turnover rate. Empirical research shows that both a larger firm size and a lower turnover rate increase the probability of training.

In contrast to investment in training, workers' learning-by-doing occurs as a by-product of producing. However subsection 3.2 showed that the concept of learning-by-doing is widely used, not only to indicate learning at the individual level (embodied knowledge) but also to indicate learning at the firm level (disembodied knowledge) and incremental technical change (disembodied knowledge), including spillovers from other firms. Empirical research has defined the learning curve, which describes the relationship between the diminishing rate of productivity growth with cumulated output at the sector or the firm level. Various kinds of learning were summarized in diagram III. Learning-by-doing by individual workers is usually regarded as part of on-the-job training. At the individual level, the firm can stimulate learning by creating jobs with learning opportunities for employees. Knowledge can also be acquired by learning-by-doing at the firm level. In that case learning is usually not regarded as part of on-the-job training. The embodied knowledge of both workers and managers or owners consists of general and specific skills. In a model suggested by Rosen (1972b), the knowledge acquired by learning may be vested in the firm or in managers or owners, and is a function of either outputs or inputs.

Subsection 3.3 discusses the substitutability of the various forms of human capital. According to human capital theory, initial education may be complementary to, or substitutable for, training or learning-bydoing. The latter two forms of human capital are part of on-the-job training (excluding formal training by training institutions, see diagram II) and are often approximated by years of experience at the individual level. On the other hand, the screening theory and Thurow's labour queue theory indicate that initial education and training are complementary. Empirical research seems to point to the complementarity of initial education and other forms of human capital, whereas over-educated workers seems to require less training or experience. Nevertheless, the results of the different empirical studies are sometimes contradictory, because the correlation between various forms of human capital may be dependent on the occupation of the employees. Moreover, the fact that empirical studies focus on various training methods (formal or informal, general or specific) may lead to different conclusions with regard to the substitutability of education and training. Formal training methods are particularly used in jobs or firms in which initial education or general training is important, whereas informal training methods are particularly 
used when experience or specific training is important. Furthermore, there seems to be an optimal mix (i.e. complementarity) between different forms of initial education, for example between general education on the one hand and vocational and technical education (VOTEC) on the other hand.

Subsection 3.4 shows that the obsolescence of human capital can have two causes. Physical depreciation occurs especially when workers grow older in occupations in which great physical effort is required. Economic depreciation, in contrast, is not directly linked to age, but, like the economic depreciation of physical capital, is linked to technical change. However the productivity of older workers, in particular, seems to decline, which may increase the incentives to retire older workers early or to certify them as unable to work. A human resource policy or a training policy suited to the needs of older workers (or both) might prevent this loss of productivity.

Finally, section 4 tries to clarify the linkages between technological change and investments in human capital. Subsection 4.1 highlights the difference between technological change and technical change. The former refers to the development of knowledge available for the production of goods, whereas the latter refers to the actual production techniques which are in use. Section 4.2 argues that both learningby-doing and research and development (R\&D) produce technological knowledge. In learning-by-doing, the knowledge which is produced is a by-product of the production of goods, whereas R\&D takes place in a laboratory setting. Higher education, in particular, is an important input factor in research and development. Moreover, the outcome of the R\&D process is called technological knowledge and can be measured by, for example, the number of blueprints produced (or patents awarded). As can be seen in diagram I, both human capital and technological knowledge are inputs for new R\&D activities. The fact that part of the output of R\&D, i.e. technological knowledge, can be used for the production of new R\&D derives from two important features of knowledge which distinguish it from human capital, viz. nonrivalry and non-excludability. Furthermore, subsection 4.2 showed that the marginal productivity of human capital increases when the available level of technological knowledge increases, i.e. when there are more opportunities for technological diffusion. Finally, subsection 4.3 discusses some empirical research which indicates that the demand for human capital increases if there is a change in the production techniques. Both capital-skill complementarity and technology-skill complementarity are responsible for this increase.

We have now shed light on the role of human capital in the firm with regard to, inter alia, wages, productivity, the demand for labour, production and technical and technological change. Human capital is not only an input factor in the firm production function, like uneducated labour and physical capital, it also increases technological diffusion and contributes to the production of technological knowledge and R\&D. The various roles of human capital are indicated by the lowest, the middle and the highest arrow, respectively, coming from the label "Human Capital Stock of Firm" in diagram I. Moreover, the worker effect, the allocative effect and the signalling effect indicate the first role of human capital, the diffusion effect the second role of human capital and the research effect the third role of human capital. The firm can acquire human capital by hiring new workers with a particular level of initial schooling, by training workers (diagram II) and by learning-by-doing (diagram III).

\section{References}

Arrow, K.J. (1962), The Economic Implications of Learning-by-Doing, Review of Economic Studies, vol. 29, pp. 155-173. 
Arrow, K.J. (1973), Higher Education as a Filter, Joumal of Public Economics, pp. 193-216.

Barro R.J. and J.W. Lee (1993), International Comparisons of Educational Attainment, Working Paper No. 4349, NBER.

Barron, J.M., D.A. Black and M.A. Loewenstein (1989), Job Matching and On-the-job Training, Journal of Labor Economics, vol. 7, no. 1.

Bartel, A.P. (1991a), Employee Training Programs in U.S. Businesses, in: D. Stern and J.M.M. Ritzen (eds.), Market Failure in Training? New Economic Analysis and Evidence on Training of Adult Employees, Springer-Verlag, Berlin, Heidelberg.

Bartel, A.P. (1991b), Productivity Gains from the Implementation of Employee Training Programs, Working Paper No. 3893 , NBER.

Bartel, A.P. and F.R. Lichtenberg (1987), The Comparative Advantage of Educated Workers in Implementing New Technology, Review of Economics and Statistics, February, pp. 1-11.

Bartel, A. and N. Sicherman (1990), Technological Change and the Careers of Older Workers, Working Paper No. 3433 , NBER.

Becker, G.S. (1975), Human capital, A theoretical and empirical analysis, with special reference to education, second edition, Chicago/London.

Berman, E., J. Bound and Z. Griliches (1993), Changes in the Demand for Skilled Labour within U.S. Manufacturing Industries: Evidence from the Annual Survey of Manufacturing, NBER, Working Paper No. 4255.

Bishop, J.H. (1991), On-The-Job Training of New Hires, in: D. Stern and J.M.M. Ritzen (eds.), Market Failure in Training? New Economic Analysis and Evidence on Training of Adult Employees, Springer-Verlag, Berlin, Heidelberg.

Blaug, M. (1970), Introduction to the Economics of Education, Penguin Books, London.

Blaug, M. (1976), The Empirical Status of Human Capital Theory: a Slightly Jaundiced Survey, Joumal of Economic Literature, pp. 827-850.

Blaug, M. (1985), Where Are We Now in the Economics of Education?, Economics of Education Review, vol. 4 (1), pp. 1728.

Bowman, M.J. (1974), Learning and Earning in the Postschool Years, in: F.N. Kerlinger and J.B. Carroll (eds), Review of Research and Education, 2, Itaxa IL: Peacock, pp. 202-44.

Bowman, M.J. (1987), On-The-Job Training, in: Psacharopoulos, G. (ed.), Economics of Education: Research and Studies, Pergamon Press, Oxford, pp. 24-29.

Broer, D.P. and W.J. Jansen (1989), Employment, Schooling and Productivity Growth, De Economist, vol. 137, nr. 4, pp. 425-453.

Butter, F. den and F. Wollmer (1993), Endogene Groei en Technologie, Tijdschrift voor Politieke Ekonomie, vol. 16, nr. 2. CBS (1992), Bedrijfsopleidingen 1990, Voorburg/Heerlen.

Cohen W.M. and D.A. Levinthal (1989), Innovation and Learning: the Two Faces of R\&D, The Economic Journal, September, pp. 569-596.

Dalen, H.P. van (1993), De Oudere Werknemer: van Generlei Waarde?, Economisch Statistische Berichten, 19-5-1993, pp. 449-453.

Dam, J.W. van and G.W.M. Ramaekers (1992), Technology Indicators: Population, Labour and Schooling, Report 1992/5E, ROA.

Ehrenberg, R.G. and R.S. Smith (1993), Modern Labor Economics, Theory and Public Policy, Fifth Edition, Harper Collins.

Ewijk, C. van (1993), Kennis en Groei: de Gevolgen van de Nieuwe Groeitheorie, Economisch Statistische Berichten, 1-91993, pp. 788-793.

Fallon, P.R. (1987), Labour Quality and Education, in: Psacharopoulos, G. (ed.), Economics of Education: Research and Studies, Pergamon Press, Oxford, pp. 116-121.

Freeman, C. and L. Soete (1987; eds.), Technical Change and Full Employment, Basil Blackwell, Oxford.

Freeman, C. and L. Soete (1987), Factor Substitution and Technical Change, in: C. Freeman and L. Soete (eds.), Technical Change and Full Employment, Basil Blackwell, Oxford, pp. 36-48.

Gelderblom, A. and J. de Koning (1992a), Meer-jarig, Minder-waardig?, een Onderzoek naar de Invloed van Leeftijd op Productiviteit en Beloning, OSA-voorstudie V39.

Gelderblom, A. and J. de Koning (1992b), Leeftijd en functioneren. Een aanzet voor een beleid bij de rijksoverheid, Nederlands Economisch Instituut, Dutch Ministry for Internal Affairs. 
Gelderblom, A. and J. de Koning (1993), Het Functioneren van Oudere Werknemers en Training, Concept, Paper voor de Nederlands Arbeidsmarktdag 27 October 1993.

Green, F. (1993), The Determinants of Training of Male and Female Employees in Britain, Oxford Bulletin of Economics and Statistics, 55, 1.

Griliches, Z. (1969), Capital-Skill Complementarity, Review of Economics and Statistics, November, pp. 465-486.

Griliches, Z. (1970), Notes on the Role of Educaton in Production Functions and Growth Accounting; in W.L. Hansen (ed.), Education, Income and Human Capital, NBER, Columbia University Press, New York and London, 1970.

Grip, A. de (1987), Onderwijs en Arbeidsmarkt: Scholingsdiscrepanties, thesis, VU-uitgeverij, Amsterdam.

Grip, A. de and W.J. Nusselder (1989), Technology Indicators Referring to Education and Labour, Report 1989/4E, ROA.

Grip, A. de, L.F.M. Groot, J.A.M. Heijke and E.J.T.A. Willems (1990), De aans/uiting tussen beroepen en functies en de relatie met scholings- en mobiliteitsprocessen, OSA working document $W 80$, Den Haag.

Groot, W. (1993a), Wage and Productivity Effects of Enterprise-related Training, Department of Economics, Leiden University.

Groot, W. (1993b), Overeducation and the Returns to Enterprise-related Schooling, Economics of Education Review, Vol.12, No. 4, pp. 299-309.

Groot, L.F.M. and A. de Grip (1991), Technological Change and Skill Formation in the Bank Sector, Economics of Education Review, Vol. 10(1), pp. 57-71.

Grossman G.M. and E. Helpman (1992), Innovation and Growth in the Global Economy, second printing, MIT Press, Cambridge, etc.

Hartog, J. (1988), An Ordered Response Model for Allocation and Earnings, Kyklos, Vol. 41, pp. 113-141.

Hartog, J. (1992), Capabilities, Allocation and Eamings, Norwell, Mass. and Dordrecht, Kluwer Academic.

Hartog, J. (1993), On Human Capital and Individual Capabilities, Invited lecture, European Association of Labour Economists meeting, Maastricht, October.

Hashimoto, M. (1981), Firm-Specific Human Capital as a Shared Investment, The American Economic Review, 71, pp. 47582.

Hashimoto, M. and J. Raisian (1992), Employment Tenure and Earnings Profiles in Japan and the United States: Reply, The American Economic Review, Vol. 82, No.1.

Hebbink, G.E. (1992), Human Capital, Labor Demand and wages: Aspects of Labor-Market Heterogeneity, Tinbergen Institute Research Series, nr. 35, Thesis Publishers, Amsterdam.

Hersch, J. (1991), Education Match and Job Match, Review of Economics and Statistics, pp. 140-144.

Hill, E.T. (1991), Post-Secondary Vocational Education and On-The-Job Training, Applied Economics, 23, pp. 197-208.

Howell, D.R. and E.N. Wolff (1992), Technical Change and Demand for Skills, Cambridge Journal of Economics, 16(2), June, pp. 127-146.

Huffman, W.E. (1977), Allocative Efficiency: the Role of Human Capital, Quarterly Journal of Economics, February, pp. 5980.

Jaffe, A.B. (1989), Real Effects of Academic Research, The American Economic Review, Vol. 79, No. 5, pp. 957-70.

Katz, E. and A. Ziderman (1990), Investment in General Training: The Role of Information and Labour Mobility, The Economic Journal, 100, pp. 1147-1158.

Killingsworth, M.R. (1982), "Learning by Doing" and "Investment in Training": A Synthesis of Two "Rival" Models of the Life Cycle, Review of Economic Studies, XLIX, pp. 263-271.

Koning, J. de, A. Gelderblom, M. Koss, R. Olieman (1990), Soorten Onderwijs en Economische Groei, Nederlands Economisch Instituut, Rotterdam.

Lockheed, M.E. (1987), Farmers' Education and Economic Performance, in: Psacharopoulos, G. (ed.), Economics of Education: Research and Studies, Pergamon Press, Oxford, 1987, pp. 110-116.

Lucas, R.E.B. (1988), On the Mechanisms of Economic Development, Journal of Monetary Economics, 22, pp. 3-42.

Lynch, L.M. (1992), Private Sector Training and the Earnings of Young Workers, The American Economic Review, Vol. 82 , No. 1.

Mairesse, J. and M. Sassenou (1991), R\&D and Productivity: A Survey of Econometric Studies at the Firm Level, STI Review, 8, p. 9-43. 
Malerba, F. (1992), Learning by Firms and Incremental Technical Change, The Economic Journal, 102, pp. 845-859.

McMahon, W.W. (1984), The Relation of Education and R\&D to Productivity Growth, Economics of Education Review, pp. 299-313.

McMahon, W.W., J.H. Jung and Boediono (1992), Vocational and Technical Education in Development: Theoretical Analysis of Strategic Effects on Rates of Return, Economics of Education Review, Vol. 11(3), pp. 181-194.

Mincer, J. (1974), Schooling, Experience, and Earnings, NBER, Columbia University Press, New York and London.

Mincer, J. (1984), Human Capital and Economic Growth, Economics of Education Review, vol. 3, pp. 195-205.

Mincer, J. (1989a), Human Capital Responses to Technological Change in the Labor Market, NBER, Working Paper No. 3207.

Mincer, J. (1989b), Job Training, Costs, Returns and wage Profiles, NBER Working Paper no. 3208.

Mincer, J. (1989c), Human Capital, Technology, and the wage Structure: What Do Time Series Show?, NBER, Working Paper No. 3581.

Mincer, J. (1989d), Human Capital and the Labor Market: A Review of Current Research, Educational Researcher, 18(5), May, pp. 27-34.

Nelson, R.R. and E.S. Phelps (1966), Investment in Humans, Technological Diffusion and Economic Growth, American Economic Review Papers and Proceedings, pp. 69-75.

OECD (1991), Enterprise-related Training, Employment Outlook, Ch. 5, Paris.

OECD (1993), Enterprise Tenure, Labour Turnover and Skill Training, Employment Outlook, Ch. 4, Paris.

Parker, J.E.S. (1978), The Economics of Innovation, The national and multinational enterprise in technological change, second edition, Longman, London.

Pattel, P. and L. Soete (1988), Measuring the Economic Effects of Technology, STI Review, December, p. 121-166.

Pencavel, J. (1991), Higher Education, Productivity, and Earnings: A Review, Joumal of Economic Education, pp. 331-359.

Psacharopoulos, G. (1987; ed.), Economics of Education: Research and Studies, Pergamon Press, Oxford.

Ram, R. (1980), Role of Education in Production: A Slightly New Approach, Quarterly Joumal of Economics, pp. 365-373.

Rasmussen, D.W. and I. Kim (1992), The Growth of US Labour Productivity 1950-1989, Applied Economics, 24, pp. 285289

Reijnen, J.O.N. and A.H. Kleinknecht (1992), Technologie en de Vraag naar Arbeid, OSA werkdocument W 107.

Ritzen, J.M.M. (1989), Market Failure for General Training, and Remedies, in: D. Stern and J.M.M. Ritzen (eds.), Market Failure in Training? New Economic Analysis and Evidence on Training of Adult Employees, Springer-Verlag, Berlin, Heidelberg.

Romer, P.M. (1986), Increasing Returns and Long Term Run Growth, Journal of Political Economy, vol. 94, pp. 1002-1037.

Romer, P.M. (1990), Endogenous Technological Change, Journal of Political Economy, 94, pp. 1002-1037.

Rosen, S. (1972a), Learning and Experience in the Labor Market, Journal of Human Resources, 7(3), pp. 336-342.

Rosen, S. (1972b), Learning by Experience as Joint Production,

Quarterly Journal of Economics, 86(3), pp. 366-382.

Sattinger, M. (1993), Assignment Models of the Distribution of Earnings, Joumal of Economic Literature, Vol. XXXI, pp. 831880.

Schultz, T.W. (1961), Investments in Human Capital, American Economic Review, pp. 1-17.

Shell, K. (1967), A Model of Inventive Activity and Capital Accumulation, in: K. Shell (ed.), Essays on the Theory of Optimal Growth, MIT Press, Cambridge Mass., pp. 67-85.

Sicherman, N. (1991), "Overeducation" in the Labor Market, Journal of Labor Economics, vol. 9, no. 2.

Soete, L. (1987), Employment, Unemployment and Technical Change: A Review of the Economic Debate, in: C. Freeman and L. Soete (eds.), Technical Change and Full Employment, Basil Blackwell, Oxford, pp. 36-48.

Solow, R.M. (1957), Technical Progress and the Aggregate Production Function, Review of Economics and Statistics, Vol. 39 , pp. 312-320.

Spence, O.F. (1973), Job Market Signalling, Quarterly Journal of Economics, pp. 355-374.

Stern D. and J.M.M. Ritzen (1991; eds.), Market Failure in Training? New Economic Analysis and Evidence on Training of Adult Employees, Springer-Verlag, Berlin, Heidelberg. 
Thurow, L.C. (1975), Generating Inequality, MacMillan, New York.

Tinbergen, J. (1975), Income Distribution, Analysis and Policies, North-Holland, Amsterdam, Oxford.

Verspagen, B. (1992), Uneven Growth between Interdependent Economies, University of Limburg, Dissertation no. 92-10, UPM, Maastricht.

Verspagen, B. and L. Soete (1993), Onderwijs en Onderzoek: Voedingsbodem voor Groei, Economisch Statistische Berichten, 22-9-1993, pp. 876-879.

Welch, F. (1970), Education in production, Journal of Political Economy, May, pp. 35-59.

Winkler, D.R. (1987), Screening Models and Education, in: Psacharopoulos, G. (ed.), Economics of Education: Research and Studies, Pergamon Press, Oxford, pp. 287-291.

Woodhall, M. (1987a), Human Capital Concepts, in: Psacharopoulos, G. (ed.), Economics of Education: Research and Studies, Pergamon Press, Oxford, pp. 21-24.

Woodhall, M. (1987b), Earnings and Education, in: Psacharopoulos, G. (ed.), Economics of Education: Research and Studies, Pergamon Press, Oxford, pp. 209-217.

Wozniak, G.D. (1987), Human Capital, Information, and the Early Adoption of New Technology, Journal of Human Resources, vol. 22, Winter, pp. 101-112. 


\section{Appendix A}

Diagram I

Human capital accumulation at the firm level

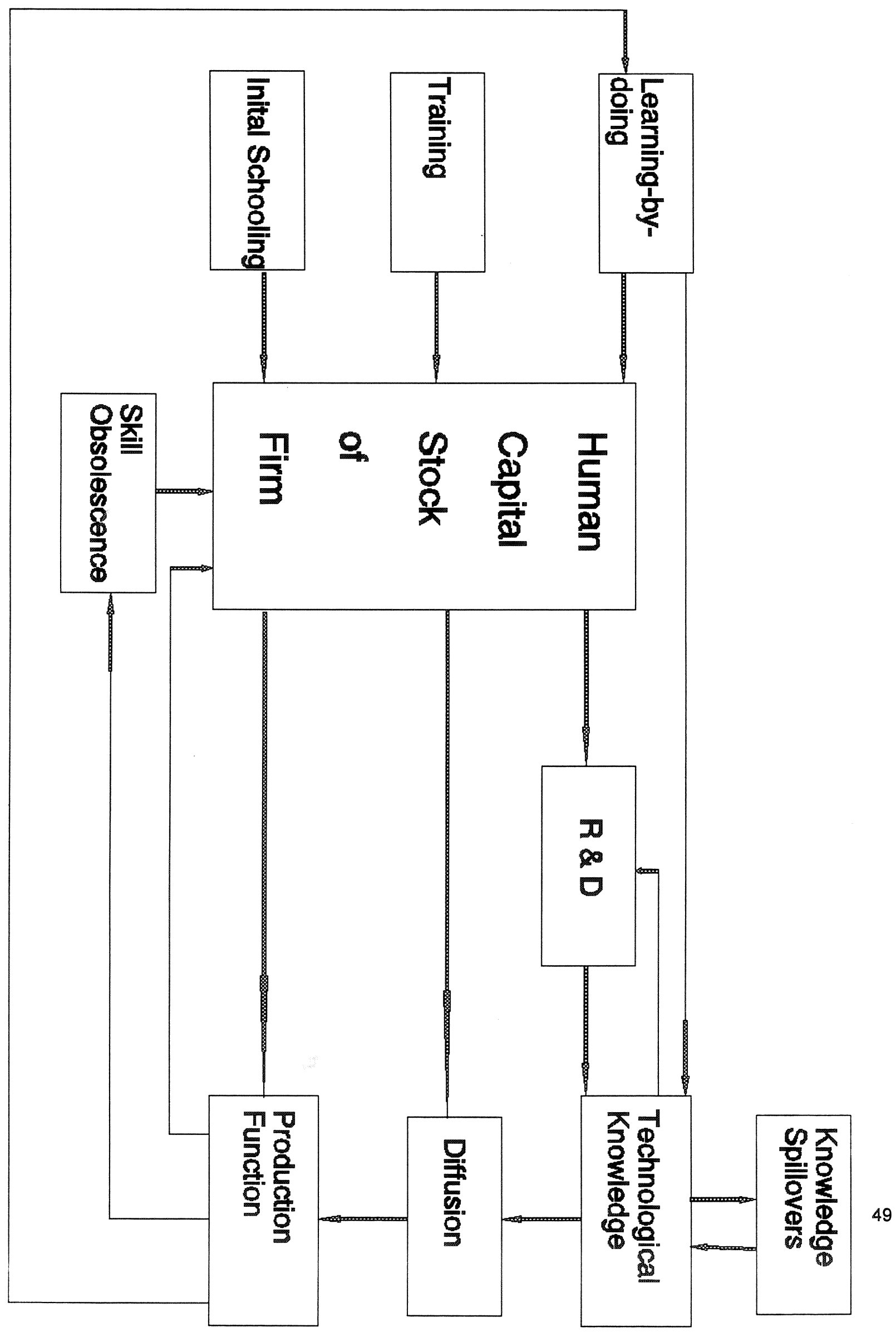


Diagram II

Various kinds of investment in training

\begin{tabular}{|c|c|c|}
\hline & external to the firm & internal to the firm \\
\hline formal & $\begin{array}{l}\text { "training courses organized } \\
\text { by training institutions } \\
\text { (also for workers of other } \\
\text { firms) } \\
\text { " general skills }\end{array}$ & $\begin{array}{l}\text { " training courses provided } \\
\text { by the firm itself } \\
\text { " apprenticeships } \\
\text { " introductory programmes } \\
\text { " general and specific skills } \\
\text { " part of on-the-job training }\end{array}$ \\
\hline informal & & $\begin{array}{l}\text { " demonstrations } \\
\text { " instructions } \\
\text { " supervision } \\
\text { " task rotations } \\
\text { " consultancy } \\
\text { " help } \\
\text { " general and specifc training } \\
\text { " part of on-the-job training }\end{array}$ \\
\hline
\end{tabular}

Diagram III

Various kinds of learning-by-doing

\begin{tabular}{|c|c|c|}
\hline & external to the firm & internal to the firm \\
\hline $\begin{array}{l}\text { firm } \\
\text { level }\end{array}$ & $\begin{array}{l}\text { " spillovers to and from } \\
\text { other firms } \\
\text { * disembodied } \\
\text { technological knowledge }\end{array}$ & $\begin{array}{l}\text { * vested in firms as an } \\
\text { asset of the firm } \\
\text { * firm as an 'entity' has } \\
\text { positive market value, } \\
\text { e.g. goodwill and }\end{array}$ \\
\hline $\begin{array}{l}\text { individual } \\
\text { level }\end{array}$ & & $\begin{array}{l}\text { * vested in managers or } \\
\text { owners } \\
\text { * work experience of em- } \\
\text { ployees as a by-product } \\
\text { * relation with } \\
\text { age-earnings porfiles } \\
\text { * general and specific } \\
\text { skills (embodied } \\
\text { knowledge) } \\
\text { "part of on-the-job training }\end{array}$ \\
\hline
\end{tabular}




\section{Appendix B}

In this appendix we want to show that an increase in human capital per worker shifts the labour demand curve to the right under the assumption of a Cobb-Douglas production function with a fixed stock of physical capital. This implies that the production function of equation (2.1) can be specified as follows.

$$
Y=f(L)=A L^{\alpha} ; \quad 0<\alpha<1
$$

where $A$ is an exogenous variable indicating the production technique and $\alpha$ is a parameter. Moreover, we use the specification of the effective labour input of equation (A.2), which is similar to equation (2.5).

$$
L=N H
$$

We can differentiate equation (A.1) with respect to the number of workers $N$, which results in the marginal productivity per worker with human capital $H$ per worker. Therefore the marginal productivity may be equated to the real wage $w$ as in equation (A.3).

$$
L=\left(\frac{w}{A \alpha H}\right)^{\frac{1}{\alpha-1}}
$$

Rewriting equation (A.3) as an equation for the demand for effective labour results in

$$
\frac{\partial Y}{\partial N}=A \alpha L^{\alpha-1} H=w
$$

Equation (A.4) shows that the demand for effective labour is dependent on the real wage per worker divided by the amount of human capital per worker. If the real wage decreases, given the amount of human capital per worker, the demand for effective labour increases. Nevertheless, what counts for the demand of effective labour is the real wage per unit of human capital, i.e. $W / H$. If $W / H$ decreases by improving the qualifications of workers, the real wage per unit of human capital becomes cheaper, which results in a higher demand for effective labour. However, usually it is more interesting to know how many workers are demanded, rather than the demand for effective labour. Therefore we can substitute equation (A.2) into (A.4) and rewrite it. As in subsection 2.3, we can distinguish two effects of human capital that work in the opposite direction.

$$
N=H_{2}^{-1}\left(\frac{W}{A \alpha}\right)^{\frac{1}{\alpha-1}} H_{1}^{-\frac{1}{\alpha-1}}
$$

Again, $H_{1}$ indicates the effect on the wage costs per unit of human capital. On the other hand, $H_{2}$ indicates the possibility of substituting the number of workers employed for the amount of human capital per worker. If the amount of human capital per worker increases, the former effect increases and the latter effect decreases the demand for the number of workers. The net effect is an increase in the demand for workers (under the assumptions of this appendix), which is shown by equation (A.6).

$$
N=\left(\frac{W}{A \alpha}\right)^{\frac{1}{\alpha-1}} H^{\frac{\alpha}{1-\alpha}}
$$


Equation (A.6) implies that the labour demand curve is downward sloping and convex. Moreover, it shows that increasing the amount of human capital per worker $H$ shifts the labour demand curve to the right. 